\title{
Integrated genomics, physiology and breeding approaches for improving drought tolerance in crops
}

\author{
Reyazul Rouf Mir • Mainassara Zaman-Allah • \\ Nese Sreenivasulu $\cdot$ Richard Trethowan • \\ Rajeev K. Varshney
}

Received: 11 January 2012/Accepted: 18 May 2012/Published online: 14 June 2012

(C) The Author(s) 2012. This article is published with open access at Springerlink.com

\begin{abstract}
Drought is one of the most serious production constraint for world agriculture and is projected to worsen with anticipated climate change. Inter-disciplinary scientists have been trying to understand and dissect the mechanisms of plant tolerance to drought stress using a variety of approaches; however, success has been limited. Modern genomics and genetic approaches coupled with advances in precise phenotyping and breeding methodologies are expected to more effectively unravel the genes and metabolic pathways that confer drought tolerance in crops. This article discusses the most recent advances in plant physiology for precision phenotyping of drought response, a vital step before implementing the genetic and
\end{abstract}

Communicated by C. Feuillet.

R. R. Mir · M. Zaman-Allah · R. K. Varshney ( $₫)$ International Crops Research Institute for the Semi-Arid Tropics (ICRISAT), Patancheru, Hyderabad 502 324, India

e-mail: r.k.varshney@cgiar.org

R. R. Mir

e-mail: imrouf2006@gmail.com

M. Zaman-Allah

e-mail: mainassara.za@gmail.com

R. R. Mir

Division of Plant Breeding and Genetics, Sher-e-Kashmir

University of Agricultural Sciences and Technology

of Jammu (SKUAST-J), Chatha, Jammu 180 009, India

M. Zaman-Allah

Department of Biology, Faculty of Sciences,

University of Maradi, BP 465, Maradi, Niger

N. Sreenivasulu

Leibniz Institute of Plant Genetics and Crop Plant Research

(IPK), 06466 Gatersleben, Germany

e-mail: srinivas@ipk-gatersleben.de molecular-physiological strategies to unravel the complex multilayered drought tolerance mechanism and further exploration using molecular breeding approaches for crop improvement. Emphasis has been given to molecular dissection of drought tolerance by QTL or gene discovery through linkage and association mapping, QTL cloning, candidate gene identification, transcriptomics and functional genomics. Molecular breeding approaches such as marker-assisted backcrossing, marker-assisted recurrent selection and genome-wide selection have been suggested to be integrated in crop improvement strategies to develop drought-tolerant cultivars that will enhance food security in the context of a changing and more variable climate. 


\section{Introduction}

Drought is the most devastating abiotic stress affecting crop productivity, which is caused by insufficient rainfall and/or altered precipitation patterns (Toker et al. 2007). The seriousness of drought stress depends on its timing, duration and intensity (Serraj et al. 2005). The impact of drought on crop production has been evidenced as early as the beginning of the seventeenth century, known as "Sahel drought", caused due to human intervention effects of deforestation, overgrazing and industrialization (Held et al. 2005). Increase in greenhouse emissions has resulted in altered precipitation, increase in arid land, desertification and finally reduction in crop productivity. Moreover, it has been causing global warming, which in turn is responsible for raising the earth's surface temperature and sea water level. As of today, climate-yield predictions are well captured in several important major crop species through simulations (Lobell et al. 2011). These important crops are in need of adaptation investments to avoid catastrophic yield losses and to meet the food demand of a fastincreasing population. Drought is often accompanied by relatively high temperatures, which promote evapotranspiration and affects photosynthetic kinetics, thus intensifying the effects of drought and further reducing crop yields. It is anticipated that the occurrence of drought in many food-producing regions will increase significantly in response to climate change (Collins et al. 2008; Reynolds and Ortiz 2010).

Tolerance to drought is a complex quantitative trait controlled by several small effect genes or QTLs and is often confounded by differences in plants phenology (Barnabas et al. 2008; Fleury et al. 2010). To address the complexity of plant responses to drought, it is vital to understand the physiological and genetic basis of this response. Failure to understand the molecular mechanisms of seed yield stability has hampered both traditional breeding and the use of modern genetics in the improvement of drought tolerance of crop plants (Passioura 2010; Sinclair 2011).

Recent advances in crop physiology, systematic plant phenotyping and genomics have led to new insights in drought tolerance, thus providing crop breeders with greater knowledge of the gene networks and providing new tools for plant improvement to increase crop yield (Tuberosa and Salvi 2006). While plant physiology improves our understanding of the complex network of drought tolerance-related traits thus improving selection efficiency, molecular biology and genomics approaches identify the candidate genes and quantitative trait loci (QTLs) associated with these traits. While QTLs can be deployed in crop improvement through molecular breeding, candidate genes are the prime targets for generating transgenics using genetic engineering (Varshney et al. 2011). Identification of the "most appropriate" candidate genes along with selection of "most suitable promoters" and generation of a large number of events are critical for the development of desirable transgenics with enhanced drought tolerance using know-how knowledge (http://www.plantstress.com/; for a review see Luo 2010; Varshney et al. 2011). However, the expensive regulatory process and negative public perceptions of biosafety limit the application of genetic engineering approach, while there is a wider acceptance of products generated through molecular breeding (Vogel 2009; Farre et al. 2010; Varshney et al. 2011) and Targetted Induced Local Lesions in Genome (TILLING) (see Barkley and Wang 2008).

In the last decade, several important reviews of plant drought response and tolerance have been published (http://www.plantstress.com/files/Recent_Reviews/index.asp). The importance of multifaceted strategies including genetic engineering (Bhatnagar-Mathur et al. 2008; Yang et al. 2010), physiological approaches (Sinclair 2011) and genomics approaches (Tuberosa and Salvi 2006; Cattivelli et al. 2008; Ashraf 2010; Varshney et al. 2011) have been described in several crop species (e.g. maize, Tsonev et al. 2009; rice, Leung 2008; Bernier et al. 2008; wheat, Fleury et al. 2011; soybean, Manavalan et al. 2009; pearl millet, Yadav et al. 2011; canola, Wan et al. 2009). Also, the descriptions of molecular-physiological mechanisms of drought tolerance were outlined by several reviews (Bartels and Sunkar 2005; Maggio et al. 2006; Bressan et al. 2009; Charron and Quatrano 2009). In this review, we highlight the importance of drought tolerance, especially in a variable climate and discuss the recent progress made in the area of crop physiology for precise phenotyping and genomic approaches, such as identification and cloning of QTLs and identification of candidate genes associated with drought tolerance. In addition, new molecular breeding strategies such as marker-assisted recurrent selection (MARS) and genomic selection (GS) or genome-wide selection (GWS) are discussed as options to be integrated in crop improvement programmes for developing the next generation of drought-tolerant crops.

\section{The increasing importance of drought tolerance in variable climates}

The global water shortage caused by an increasing world population and worldwide climate change is considered as one of the major challenges facing agriculture today. The combination of continued impact of drought and high temperature impairs the photosynthesis during the day-time and increases the surface temperatures in the night, which in turn increase the photorespiratory losses and thus the 
productivity. The elevated greenhouse gas concentrations may lead to the general drying of the subtropics by the end of this century, thus creating widespread drought stress in agriculture [Inter-governmental Panel on Climate Change (IPCC) 2007]. This shortage of water may threaten sustainable crop farming, since agricultural activities account for $75 \%$ of global water consumption and irrigation consumes over $90 \%$ of water used in many developing countries (UNEP 2009; Yang et al. 2010). It is also anticipated that by 2030, developing countries will be most severely affected by climate change because: (a) climate change will have the greatest impact on the tropics and subtropics, (b) most of the predicted population growth to 2030 will occur in developing countries and (c) more than half of the workforce in developing countries is involved in agriculture (Reynolds and Ortiz 2010). In brief, the convergence of population growth and variable climate is expected to threaten food security on a worldwide scale. Relatively inexpensive and easier to adapt methods would be to switch crops or altering planting seasons according to predicted precipitation patterns and continued expansion of irrigation. However, worldwide occurrence of drought has become endemic due to climate change. This raises serious concerns and places huge responsibilities on the shoulders of scientists for developing "drought-suited varieties" through molecular breeding and genetically modified approaches. However, it is clear that the demand to produce sufficient major food crops (wheat, rice and maize) for the growing population has always been increasing. Hence, optimizing yield stability for these major crops and locally important crops is essential. Therefore, maintaining food security in this scenario will require systematic approaches (see later) including the use of drought-tolerant germplasm (Reynolds and Ortiz 2010). Recent advances in plant physiology, genomics and some future breeding strategies (Fig. 1) are believed to address the multigenic nature of abiotic stresses including drought tolerance.

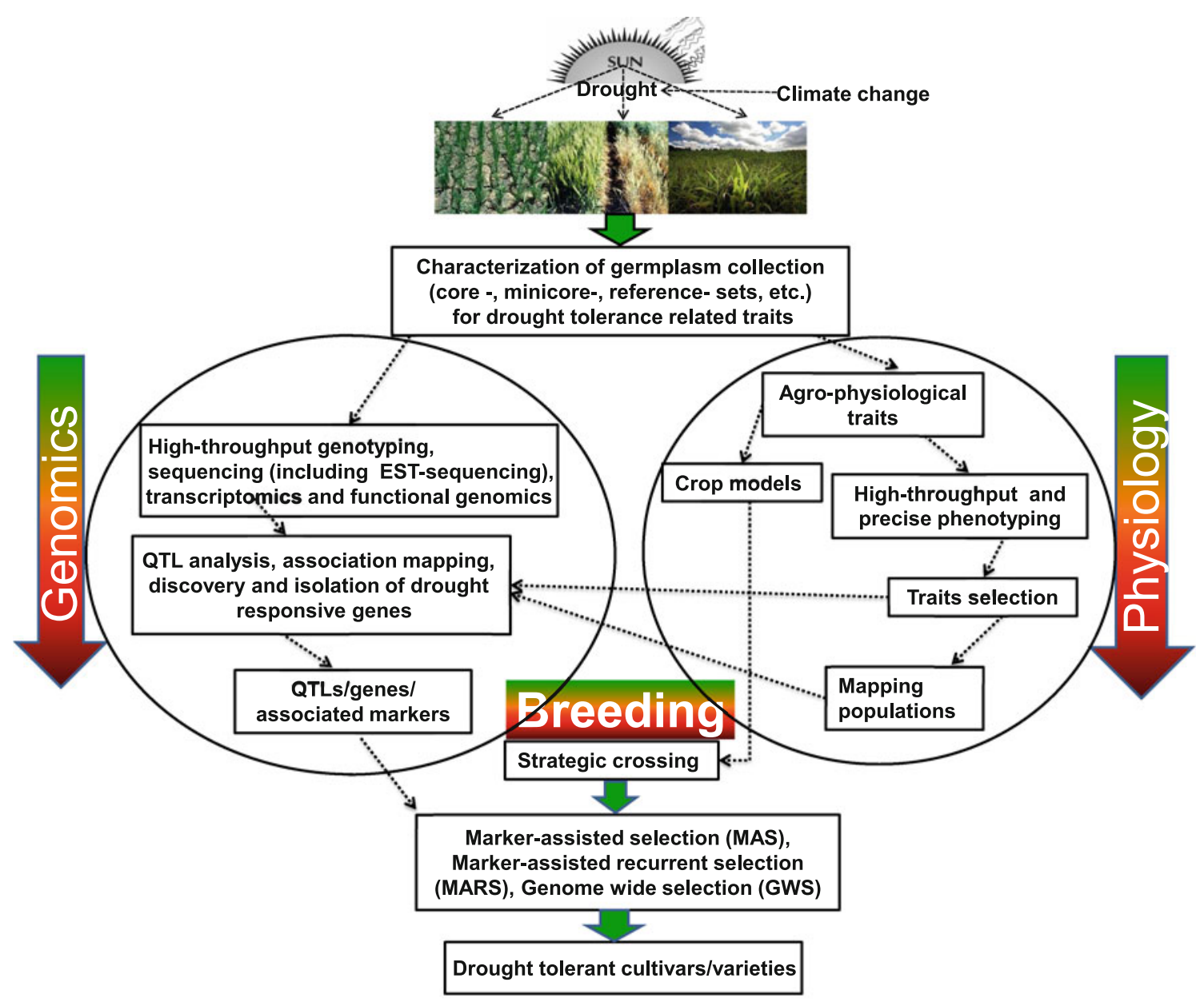

Fig. 1 A holistic approach for integrating genomics, physiology and breeding approaches for developing the superior varieties with enhanced drought tolerance 
Addressing the complexity of plant response to drought

Among the various abiotic stresses that curtail crop productivity, drought is the most recalcitrant to breeding (Tuberosa and Salvi 2006), because plants use various mechanisms to cope with drought stress. In the past, drought tolerance breeding has been hindered by the quantitative inheritance of the trait and our poor understanding of the physiological basis of yield in water-limited conditions (Sinclair 2011), as well as by limitations in technology for systematic phenotyping.

The physiological dissection of complex traits like drought is a first step to understand the genetic control of tolerance and will ultimately enhance the efficiency of molecular breeding strategies. Developing and integrating a gene-to-phenotype concept in crop improvement requires particular attention to phenotyping and ecophysiological modelling, as well as the identification of stable candidate genomic regions through novel concepts of 'genetical genomics'. Knowledge of both the plant physiological response and integrative modelling are needed to tackle the confounding effects associated with environment and gene interaction (Tardieu and Tuberosa 2010). To maximize the impact of using specific traits, breeding strategies requires a detailed knowledge of the environment where the crop is grown, genotype $\times$ environment interactions and fine tuning the genotypes suited for local environments. A physiological approach has an advantage over empirical breeding for yield per se because it increases the probability of crosses resulting in additive gene action for stress adaptation, provided that the germplasm is characterized more thoroughly than for yield alone (Reynolds and Trethowan 2007).

Criteria for using physiological traits in breeding programmes

The use of physiological traits (PTs) in a breeding programme, either by direct selection or through a surrogate such as molecular markers, depends on their relative genetic correlation with yield, extent of genetic variation, heritability and genotype $\times$ environment interactions. For instance, in drought environments, osmotic adjustment, accumulation and remobilization of stem reserves, superior photosynthesis, heat- and desiccation-tolerant enzymes, etc. are important PTs. However, it is important to establish their heritability and genetic correlation with yield in target environments. Identification of drought-adaptive PTs and mechanisms is time consuming and costly; however, if successful, the benefits are likely to be substantial. The information on important PTs can be collected on potential parental lines involving screening of entire crossing block, or a set of commonly used parents, thus producing a catalogue of useful PTs. This information can be used strategically in designing crosses, thereby increasing the likelihood of transgressive segregation events, which bring together desirable traits. However, if enough resources are available, screening for PTs could be applied to segregating generations in yield trials, or any intermediate stage, depending on when genetic gains from selection are optimal (Reynolds 2002).

It is important to note that using specific traits, breeding strategies are effective only when these traits are properly defined in terms of the stage of crop development at which they are relevant, the specific attributes of the target environment for which they are adaptive and their potential contribution to yield (Reynolds and Trethowan 2007). The early escape from progressively intensifying moisture stress, through the manipulation of plant phenology, is the most commonly exploited genetic strategy used to ensure relatively stable yields under terminal drought conditions (Richards 1991). When significant genetic diversity for a physiological trait in a germplasm collection for the given species is established, it is imperative that the relevance of the trait as a selection criterion be determined.

\section{Conceptual framework for drought adaptation}

The conceptual framework for yield drought adaptation by Passioura (1977) has three important drivers: (1) water uptake (WU), (2) water-use efficiency (WUE) and (3) harvest index (HI). These drivers stimulate trait-based breeding and genetic dissection of drought-adaptive mechanisms. Several traits have been found to be associated with the above yield component drivers. For WU, direct selection for variation in root characteristics is unfeasible; therefore, measurements associated with stomatal conductance like that of canopy temperature (CT) provide indirect indicators of water uptake by roots (see Reynolds and Tuberosa 2008). In addition, validation studies indicated that $\mathrm{CT}$ during peak stress periods was associated with $\sim 50 \%$ of the variation in water extraction in deep soil profiles and also with root length density (Reynolds et al. 2007a). For WUE, carbon isotope discrimination seems to be the best estimate and is based on higher affinity of the carbon-fixing enzyme (Rubisco) for the more common ${ }^{12} \mathrm{C}$ isotope over the less common ${ }^{13} \mathrm{C}$. A lower discrimination value indicated higher WUE. Some other traits associated with WUE included spike photosynthesis in cereals, photoprotective mechanisms including antioxidant systems, regulation of water flow via aquaporins and signalling molecules such as abscisic acid (ABA) (see Reynolds 2002; Reynolds and Tuberosa 2008). Similarly, for HI, the extreme sensitivity of reproductive processes to drought may result in the reproductive failure, which is associated with low HI, and may eliminate 
benefits associated with favourable WU or WUE. Considering the overall contributions of these three yield drivers, WU is the most important for improving the yield potential (i.e. biomass) in drought environments, while stable $\mathrm{HI}$ is associated with higher yield potential (Blum 2009; Salekdeh et al. 2009). Storage of water-soluble carbohydrates (WSC) in the stem of small grain cereals and their subsequent remobilization to grain can directly influence HI, especially under post-anthesis stress. Translocation of soluble stem carbohydrates to the grain is one of the drought-adaptive traits that relates specifically to improved partitioning, though not to reproductive growth. Remobilization of stem reserves is associated with increased levels of ABA, which presumably is involved in the triggering of enzymes prerequisite to remobilization (Reynolds 2002). The yield potential (YP), expressed as a function of the light intercepted (LI) and radiation-use efficiency (RUE) (whose product is biomass), the partitioning of biomass to yield (the HI) and the focus of improving all the three components will be undertaken through complex physiological trait (PT)-based breeding.

A general model for drought adaptation of wheat was developed by the physiologists and breeders at CIMMYT that encompasses traits which possess a potential role in dry environments (Reynolds et al. 2005). In this model, some of the important traits included: (1) pre-anthesis growth, (2) access to water as a result of rooting depth or intensity that would be expressed by a relatively cool canopy (Reynolds et al. 2005), (3) water-use efficiency (WUE) as indicated by relatively higher biomass $/ \mathrm{mm}$ of water extracted from the soil, transpiration efficiency of growth $(\mathrm{TE}=$ biomass $/ \mathrm{mm}$ water transpired) indicated by C-isotope discrimination $\left(\Delta^{13} \mathrm{C}\right)$ of leaves, and WUE of spike photosynthesis associated with refixation of respiratory $\mathrm{CO}_{2}$, (4) photoprotection including energy dissipation, anti-oxidant systems and anatomical traits such as leaf wax. The model is used to assist in taking breeding decisions by permitting a strategic approach of accumulating droughtadaptive alleles by crossing parents with contrasting drought-adaptive mechanisms. Accumulation of soluble stem carbohydrates and their remobilization during the post-anthesis drought period help to supply surplus assimilates for grain growth during grain filling (Blum 1998). Similarly, root architecture that helps to have better access to soil moisture under drought enables heat-stressed crop canopies to meet high evaporative demand associated with hot, low-relative humidity environments, thus resulting in cooler canopies (Reynolds et al. 2000). Other traits impact either WUE or RUE depending on the environmental conditions (Reynolds and Trethowan 2007).

It is therefore crucial to target specific physiological mechanisms and to identify those traits most relevant to the patterns of drought stress found in the target environment.
For example, in crops grown with residual soil moisture that experience terminal drought, such as chickpea (Cicer arietinum), genotypes with deeper, more profuse roots have an advantage through better water extraction deeper in the soil profile (Kashiwagi et al. 2005). In other crops also, deeper/profuse roots were found to increase plant access to water from deeper soil layers and support greater crop growth under drought conditions (Price et al. 2002a; Sinclair 2011). Therefore in several crops such as chickpea (Silim and Saxena 1993), wheat (Reynolds et al. 2007a) and rice (Yadav et al. 1997; Price et al. 2002a), deeper/ profuse roots are targeted to improve grain yield under rainfed conditions. However, some recent studies (ZamanAllah et al. 2011a, b) reported that selection for yield under terminal drought conditions was not essentially dependent on deeper/profuse root systems, but rather on several other critical traits that contribute to soil moisture conservation during late season water deficits. These traits include: (1) low leaf conductance under non-limited water conditions during the vegetative stage, which could be measured by a warmer canopy, (2) a low leaf expansion rate when soil moisture is still non-limiting for plant growth and a restriction of plant growth under progressive exposure to stress and (3) a higher fraction of transpirable soil water (FTSW) thresholds that reduce transpiration, thus avoiding rapid soil water depletion (Fig. 2). Several studies have shown that FTSW can be linked to variables describing plant water status such as midday leaf water potential, leaf relative water content and stomatal conductance (Sinclair and Ludlow 1986; Pellegrino et al. 2007), which are known to contribute to drought adaptation.

In addition to the above positive effects of the staygreen trait, enhanced remobilization of stored carbohydrates will lead to identify the important targets for enhancing seed sink strength under drought, thus helping to achieve yield stability under drought (for further details refer reviews by Sreenivasulu et al. 2007; Mittler and Blumwald 2010). Although, in general, photosynthesis is markedly reduced under drought stress, many dicot species are dependent on assimilates produced from current photosynthesis under drought and, therefore, exploring genotypes possessing efficient mechanisms of stay green will be beneficial. On the contrary, monocarpic cereal species seem to prefer assimilates produced prior to flowering (pre-anthesis assimilate), which is stored in the vegetative tissue, mainly in the stem in the form of various soluble sugars translocated through the trigger of remobilization events where $\mathrm{ABA}$ plays an important role (Yang and Zhang 2006; Zhang et al. 2009; Seiler et al. 2011). These traits were not all present in a single genotype, reflecting the complexity of drought tolerance and the need to pyramid several beneficial traits through plant breeding. 

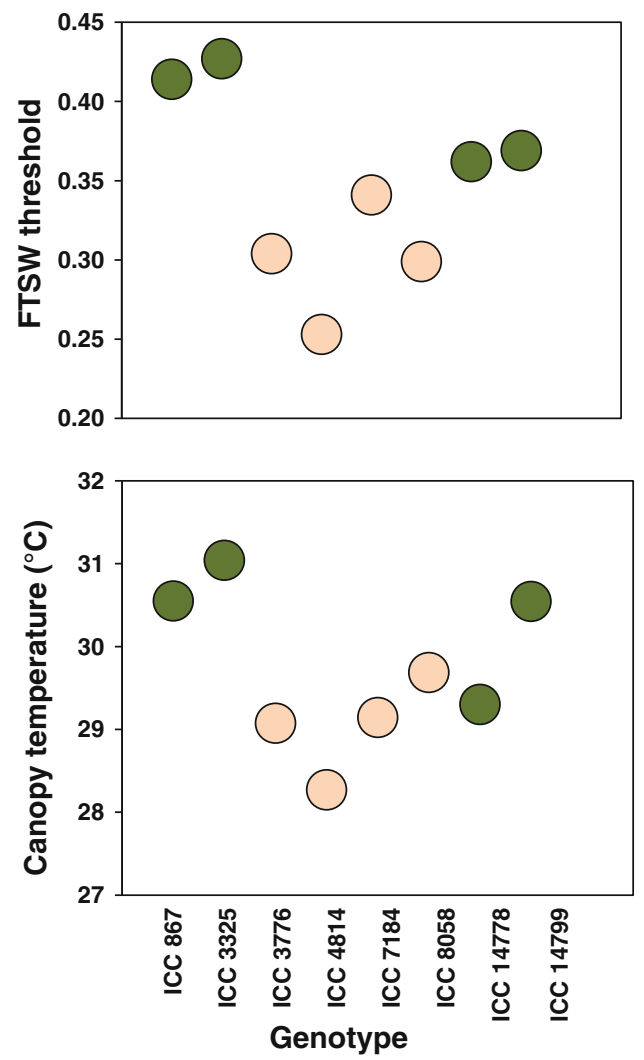

Fig. 2 An example of involvement of several physiological traits for conferring terminal drought tolerance in chickpea. A set of eight chickpea genotypes including four tolerant (ICC 14799, ICC 867, ICC14788 and ICC 3325) and four susceptible (ICC 4814, ICC 8058, ICC 3776 and ICC 7184) to drought stress (green filled circle tolerant and orange filled circle sensitive) have been characterized for: canopy temperature $\left({ }^{\circ} \mathrm{C}\right)$ and canopy conductance $\left(\mathrm{mg} \mathrm{H}_{2} \mathrm{O} \mathrm{m}^{-2} \mathrm{~h}^{-1}\right)$

\section{Strategic trait-based crossing}

The conceptual models of drought-adaptive traits have been found useful for accumulating complementary PTs in selected progeny. The key steps in this type of PT breeding include: (1) characterization of crossing block lines for stress-adaptive mechanisms, (2) strategic crossing among parents with different but potentially complementary PT expression, thus ensuring cumulative gene action in selected progeny, and (3) early generation selection (EGS) of bulks for canopy temperature (CT). This type of physiological characterization is used to assess variation and thereby increases the rates of genetic gains (Reynolds and Tuberosa 2008; Reynolds et al. 2009a). The main objective of strategic trait-based crossing is to accumulate traits that will be complementary for a given target environment. Under water-limited situations, traits that improve water uptake, water use efficiency and partitioning to yield, respectively, are likely to work synergistically to maximize productivity in the target environment (Passioura 1977; see Reynolds et al. 2009a). This has resulted in the distribution
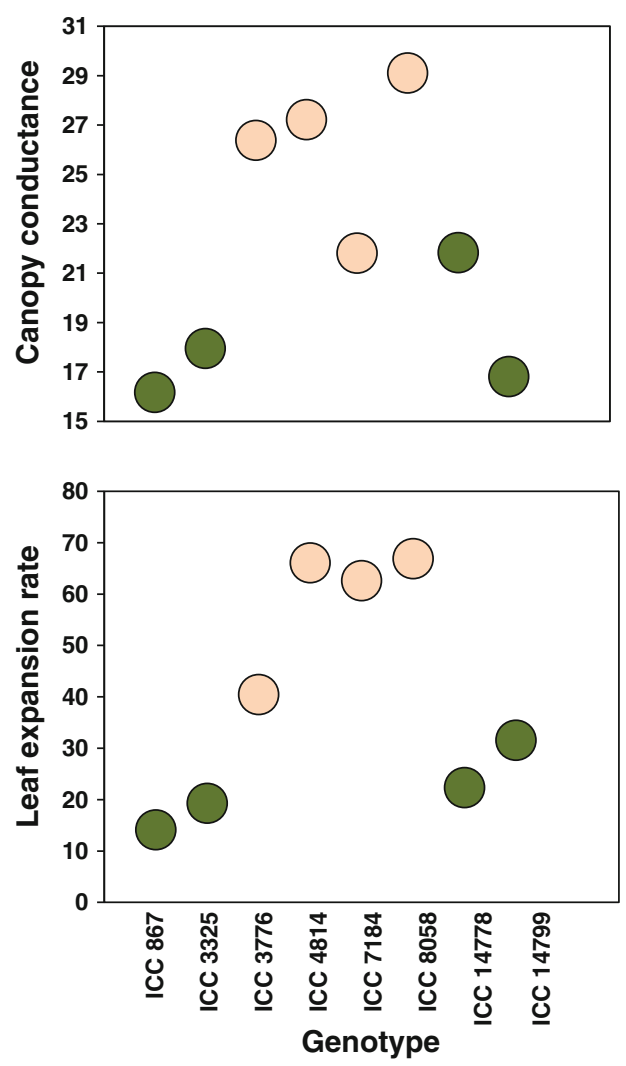

measured at 42 DAS under well-watered conditions; fraction of transpirable soil water (FTSW) threshold measured in plants exposed to progressive water stress and leaf expansion rate (LER; $\mathrm{cm}^{2} \mathrm{day}^{-1}$ ), measured between 42 and 56 DAS. Susceptible genotypes tended to have lower canopy temperature and FTSW, but higher canopy conductance and LER as compared to tolerant genotypes (color figure online)

of advanced lines to rain-fed environments worldwide by the International Maize and Wheat Improvement Center (CIMMYT) and it has been confirmed that PT crossing results in cumulative gene action in selected progeny, resulting in increased yield under drought environments (Reynolds et al. 2005, 2007b; Reynolds and Tuberosa 2008). Characterization of candidate parents for better targeted crossing should have the highest priority in terms of physiological interventions in breeding for a number of reasons including: (1) since a large investment is needed in trait measurement and the information obtained can be used for many generations of crossing once the initial characterization has been made, (2) the number of lines in a crossing block are relatively small $(\sim 100 /$ target environment) and the detailed characterization is even possible for traits which are relatively time-consuming, e.g. for traits like soil moisture depletion or stem carbohydrates.

The genetic gains in yield can be accelerated by incorporating complex PTs deterministically in modern plant breeding in addition to simply agronomic inherited traits like plant height, flowering time, resistance to prevalent 
diseases, quality parameters and yield based on multilocation trials (Braun et al. 2010; Reynolds et al. 2011). PTbased breeding approaches have been already implemented successfully in Australian breeding programmes (Rebetzke et al. 2009) as well as by CIMMYT, leading to international distribution of a new generation of elite droughtadapted lines (Reynolds et al. 2009b).

\section{Precise phenotyping for drought tolerance and related dynamic traits}

After establishing the most suitable target trait for selecting grain yield under drought stress, the next step is to establish a high-throughput precision phenotyping platform for pinning down the source trait most tightly connected to yield (Tuberosa 2010). The precise phenotyping of drought-related PTs often requires the utilization of sophisticated and expensive techniques herein listed:

Near-infrared (NIR) spectroscopy on agricultural harvesters

This method provides spectral information corresponding to the field plot in a single near-infrared spectrum, where physical and chemical characteristics of the harvested seed material are captured. By using calibration models (i.e. mathematical and computational operations that relate the spectral information with phenotypic values), several traits can be determined on the basis of a single spectrum (dry matter, protein, nitrogen, starch and oil content, grain texture and grain weight, etc.; Montes et al. 2007; Wiley et al. 2009; Hacisalihoglu et al. 2010). The use of NIR spectroscopy on agricultural harvesters provides indexing of grain characteristics. In contrast to conventional samplebased methods, NIR spectroscopy on agricultural harvesters secures a good distribution of measurements within plots and covers substantially larger amounts of plot material (Welle et al. 2003), thus reducing sampling error and providing more representative measurements of the plot material in terms of homogeneity.

Canopy spectral reflectance (SR) and infrared thermography (IRT)

Spectral reflectance of plant canopy is a non-invasive phenotyping technique that enables several dynamic complex traits, such as biomass accumulation, to be monitored with high temporal resolution (Montes et al. 2007). It has many advantages including easy and quick measurements, integration at the canopy level and additional parameters can also be measured simultaneously via a series of diverse spectral indices like photosynthetic capacity, leaf area index, intercepted radiation and chlorophyll content. Therefore, canopy reflectance is considered as one of the valuable tools for high-throughput phenotyping (Montes et al. 2007; Chapman 2008; Gutierrez et al. 2010). In soybean, canopy reflectance indices have been already used with great promise for measuring the effects of increasing atmospheric $\mathrm{CO}_{2}$ and $\mathrm{O}_{3}$ on soybean canopies (Gray et al. 2010).

Investigations at the individual plant level under wellcontrolled environmental conditions showed that spectral reflectance could be used to: (1) estimate the effects of environmental perturbations, such as changing atmospheric composition, on canopy structure and function (Gray et al. 2010), (2) monitor plant photosynthetic pigment composition and (3) assess plant water status and detect abiotic or biotic plant stresses (Chaerle and van der Straeten 2000; Gutierrez et al. 2010).

Plant water status as determined by plant water content or water potential (Jones 2007; Jones et al. 2009) integrates the effects of several drought-adaptive traits. Several methods are used to determine crop water content, including leaf water potential, leaf stomatal conductance and canopy temperature (CT), which is the relative measure of water flow associated with water absorption from the soil under water deficit (Reynolds et al. 2007a, b).

In addition to the above, one of the most commonly used indirect techniques for measurement of these variables is thermal infrared imaging, or infrared thermography, which involves the measurement of leaf or canopy temperature. Plant canopy temperature is a widely measured variable that is closely related to canopy conductance at the vegetative stage (Zaman-Allah et al. 2011a) and therefore provides insight into plant water status. In any given environment, stomatal variation is the dominant cause of changes in canopy temperature (Jones 2004). Although thermal imaging does not directly measure stomatal conductance, it has become a high-throughput tool for estimating differences in stomatal conductance (Merlot et al. 2002). Thermal infrared imaging for estimating conductance can be used at the whole plant or canopy level over time.

Magnetic resonance imaging (MRI) and positron emission tomography (PET)

These two methods are used at the Jülich Plant Phenotyping Centre, Germany (Heike Schneider, personal communication) to investigate root/shoot systems growing in sand or soil which allow to assess structure, transport routes and the translocation dynamics of recently fixed photoassimilates labelled with short-lived radioactive carbon isotope $\left(\delta^{11} \mathrm{C}\right)$. Quantitative MRI and PET data not only help to study differences between species, but also 
provide a phenotype within a species, the growth pattern, water relations and/or translocation properties of assimilates (Jahnke et al. 2009). Therefore, the MRI-PET combination can provide new insights into structure-function relationships of intact plants. It also allows monitoring of dynamic changes in plant properties, which have previously not been possible to assess systematically, thus improving our understanding of plant performance (such as resource use efficiency or biomass production).

\section{Nuclear magnetic resonance (NMR)}

The short half-life of $\delta^{11} \mathrm{C}$ (only $20 \mathrm{~min}$ ) limits the utility of MRI to study source-sink relationships in minute structures such as developing seeds (Jahnke et al. 2009). NMR provides an alternative in vivo detection platform using ${ }^{1} \mathrm{H}$ NMR and utilizes the signal emitted by protons associated with carbon nuclei, thereby sucrose and water movement may be imaged and quantified (Sardans et al. 2010; Melkus et al. 2011). Therefore, NMR technology is employed with ${ }^{13} \mathrm{C} /{ }^{1} \mathrm{H}$ double-resonant high-resolution coil to achieve better resolution for monitoring the structure of tissues like seeds through non-invasive visualization, mapping water movements and monitoring of sucrose allocation using ${ }^{13} \mathrm{C}$-labelled sucrose (Neuberger et al. 2008; Melkus et al. 2011).

\section{Integrative platforms}

One of the high-throughput integrated phenotyping platforms that includes the pipeline of imaging, image processing automatization and data handling modules was developed by LemnaTec, a German company (http://www. lemnatec.com). The platform has the capacity to measure almost unlimited sets of parameters easily, allows comprehensive screening and provides statistics on various plant traits in a dynamic way. Depending on the degree of automatization, plants are manually placed in the Scanalyzer 3D or transported on conveyor belts directly from the greenhouses to the imaging chambers. Such chambers provide top and side imaging of both shoot and root systems to quantify plant height/width, biomass and plant architecture. Application of different camera and acquisition modes-from visual light to near infrared (NIR/ SWIR), infrared (IR) and fluorescence imaging-opens new perspectives for visualization using non-destructive quantification. The key application is in the fast developing domain of plant functional genomics. These automated systems will increase our understanding of plant growth kinetics and help improve plant models for systems biology or breeding programmes.

In summary, the techniques and platforms mentioned above will greatly improve the phenotyping accuracy and throughput, thus contributing to a better elucidation of the genetic control of complex drought tolerance traits in plants. However, many of the techniques discussed above are applied to plants grown under controlled conditions that may not reflect field environment or can only be used to assess a limited number of genotypes due to high costs and/ or practicality. Therefore, to overcome this problem, multitiered selection screens, where a simple but less accurate screen allows large number of genotypes to be evaluated (first screen), followed by tiers of more sophisticated screens of decreasing numbers of genotypes have been proposed (Sinclair 2011, Fig. 3). A three-tiered sequence of physiological screens have been already used to identify candidate parental genotypes for use as parents in breeding programs for some key traits like nitrogen fixation activity during soil water deficit in soybean (Sinclair et al. 2000). Furthermore, bringing integrative phenotyping technology, such as that developed by LemnaTec, from the controlled environments to the field will improve the assessment of plant responses to drought while enabling high-throughput screening and generating comprehensive and accurate phenotypic data.

\section{Molecular dissection of drought tolerance}

In several genetic studies, drought tolerance has been found to be a complex quantitative trait controlled by a large number of minor genes/QTLs (Fleury et al. 2010; Ravi et al. 2011). Recent advances in genome mapping and functional genomics technologies have provided powerful new tools for molecular dissection of drought tolerance (Worch et al. 2011). The molecular markers and/or candidate genes identified provide a better understanding of the molecular basis of drought tolerance and, once validated, can be used in molecular breeding.

\section{QTL discovery for drought tolerance-related traits}

Traditional QTL mapping involves: (1) development of mapping populations segregating for drought tolerancerelated traits, (2) identification of polymorphic markers, (3) genotyping of the mapping populations with polymorphic markers, (4) construction of genetic maps, (5) precise phenotyping for drought tolerance-related traits, as mentioned above, and (6) QTL mapping using both genotypic and phenotypic data. This process is commonly called linkage mapping/linkage analysis-based QTL mapping (see Chamarthi et al. 2011). During the past decade, a large number of studies involving linkage mapping have been conducted in several crops to identify QTLs linked to drought tolerance (for reviews see, Cattivelli et al. 2008; Fleury et al. 2010). However, linkage mapping-based QTL 


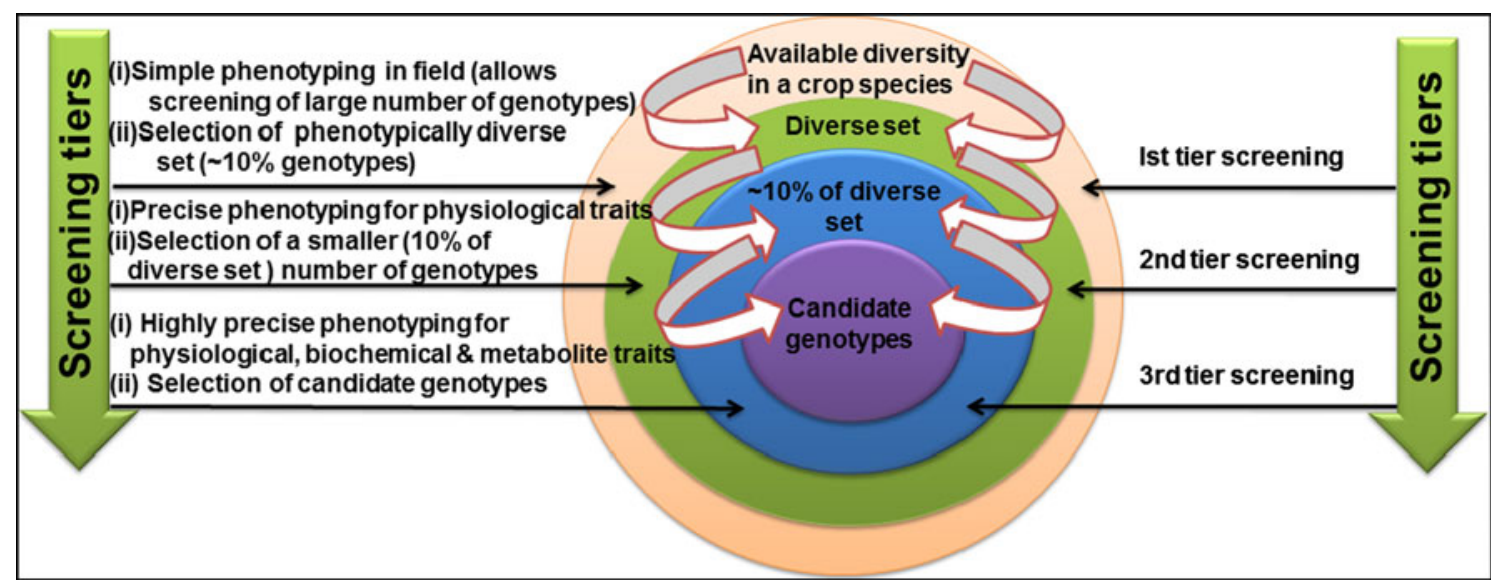

Fig. 3 An overview of three-tier screening of germplasm collection for traits related to drought tolerance. Three screening tiers are shown on the right side and the procedure of selection of germplasm followed in each tier of screening is provided on the left side

mapping does not provide precise information on QTLs because of inherent limitations associated with each mapping population. Some of these limitations are summarized by Myles et al. (2009) and include: (1) insufficient time for recombination to occur and shuffle the genome into small fragments, and as a result the QTLs identified are generally localized to large genomic regions/chromosomal segments, (2) insufficient phenotypic variation for the trait present in the mapping population and (3) segregation of different QTLs for the same trait in different mapping populations.

To overcome some of above constraints, linkage disequilibrium (LD)-based association mapping, initially used in human genetics, has been suggested as an alternative approach for QTL mapping in crop species (e.g. Myles et al. 2009; Rafalski 2010). The association mapping (AM) approach involves: (1) selection of a diverse association panel/group of individuals from a natural population/ germplasm collection, (2) precise recording of phenotypic data on the panel, (3) candidate gene sequencing or highdensity marker genotyping of the panel, (4) study of population structure (the level of genetic differentiation among groups within the selected population) and kinship (coefficient of relatedness between pairs of each individual within the population) and (5) association analysis based on information gained through population structure, kinship, and correlation of phenotypic and genotypic/haplotypic data. AM offers several advantages over bi-parental linkage mapping and these include: (1) exploitation of all the recombination events that took place during the evolutionary history of a crop species, resulting in much higher mapping resolution, (2) less time required in mapping QTL as there is no need to develop a specialized mapping population, rather a natural germplasm collection of a crop species is sufficient, (3) cost-effectiveness because the same AM panel and genotyping data can be used for mapping of different traits, (4) populations can be structured to avoid randomly generated lines (recombinant inbred lines; RILs), many of which express substandard agronomic type and (5) a higher number of alleles can be sampled compared to linkage mapping where only two alleles are usually surveyed (in apple or potato where heterozygous parental lines are used, more than two alleles/ locus can be present). Markers linked to drought tolerance traits, identified using AM, have been reported in wheat (Sanguineti et al. 2007; Maccaferri et al. 2011), barley (Ivandic et al. 2003; Baum et al. 2007; Varshney et al. 2012) and maize (Lua et al. 2010). However, obtaining a clean set of reproducible phenotypic data of drought tolerance from a larger germplasm collection for AM studies remains an open challenge even in the era of phenomicsdriven technology.

In summary, QTLs for drought tolerance have been identified for several major and important crop species like rice, maize, wheat, barley, sorghum, pearl millet, soybean and chickpea (see Table 1). These QTLs were identified for a variety of important traits including: (1) yield and yieldcontributing traits under water-deficit conditions (in the case of wheat, maize, rice, soybean and pearl millet), (2) physiological responses including water-soluble carbohydrates, carbon isotope ratio, osmotic potential, chlorophyll content, flag leaf rolling index, grain carbon isotope discrimination, relative water content, leaf osmotic potential, osmotic adjustment, chlorophyll and chlorophyll fluorescence parameters to drought stress (in the case of wheat, maize and rice), (3) flowering time including anthesis to silking interval (in maize), (4) root traits (rice, maize, wheat, soybean and chickpea), (5) stay green (sorghum) and (6) nitrogen fixation (soybean). However, so far QTL studies on the impact of drought on grain quality have not been documented. While some key QTL studies in some crop species have been summarized in Table 1, an updated compilation of mapped QTL and major genes associated 
Table 1 Summary of QTLs identified for drought tolerance-related traits in some major crop species

\begin{tabular}{|c|c|c|c|c|c|}
\hline Crop & Traits studied & $\begin{array}{l}\text { Number } \\
\text { of QTLs }\end{array}$ & $\begin{array}{l}\text { Chromosome/linkage } \\
\text { group }\end{array}$ & $\begin{array}{l}\text { Phenotypic } \\
\text { variation } \\
\text { explained } \\
\text { (PVE \%) }\end{array}$ & Reference \\
\hline \multirow[t]{11}{*}{ Rice } & Grain yield & $1(q t l 12.1)$ & 12 & 51.0 & Bernier et al. $(2007,2009)$ \\
\hline & Grain yield & 2 & 2,3 & $13.0-31.0$ & Venuprasad et al. (2009) \\
\hline & $\begin{array}{l}\text { Relative growth rate and specific } \\
\text { water use }\end{array}$ & 7 & $2,4,5,6,7,8$ & $10.0-22.0$ & Kato et al. (2008) \\
\hline & $\begin{array}{l}\text { Coleoptile length and drought } \\
\text { resistance index }\end{array}$ & 15 & All except $3,8,11$ & $4.9-22.7$ & Song-ping et al. (2007) \\
\hline & $\begin{array}{l}\text { Basal root thickness and 100-grain } \\
\text { weight }\end{array}$ & 2 & 4,6 & $20.6-33.4$ & Li-Feng et al. (2007) \\
\hline & $\begin{array}{l}\text { Grain yield and other agronomic } \\
\text { traits }\end{array}$ & 77 & All except 12 & $7.5-55.7$ & Lanceras et al. (2004) \\
\hline & Root traits & 18 & All chromosomes & $1.2-18.5$ & Ping et al. (2003) \\
\hline & Root and related traits & 42 & All chromosomes & $6.0-24.4$ & Courtois et al. (2003) \\
\hline & $\begin{array}{l}\text { Water stress indicators, phenology } \\
\text { and production traits }\end{array}$ & 47 & All except 5 & $5.0-59.0$ & Babu et al. (2003) \\
\hline & Drought avoidance & 17 & All except 9 & $4.4-25.6$ & Price et al. (2002b) \\
\hline & Osmotic adjustment & $1\left(O A_{70}\right)$ & 8 & Major & Lilley et al. (1996) \\
\hline \multirow[t]{6}{*}{ Maize } & $\begin{array}{l}\text { Yield components and secondary } \\
\text { traits }\end{array}$ & 81 & - & $0.1-17.9$ & Messmer et al. (2009) \\
\hline & Grain yield and yield components & 20 & $1,2,3,5,7,8,9$ & $4.1-31.3$ & Xiao et al. (2005) \\
\hline & $\begin{array}{l}\text { Root characteristics, drought } \\
\text { tolerance index and yield }\end{array}$ & 56 & All chromosomes & $6.7-47.2$ & Tuberosa et al. (2002) \\
\hline & Leaf ABA & $1(L-A B A)$ & 2 (bin 1.03) & 32.0 & $\begin{array}{l}\text { Tuberosa et al. (1998); } \\
\text { Landi et al. (2005) }\end{array}$ \\
\hline & Grain yield and yield components & 46 & All except 10 & $4.0-12.9$ & Ribaut et al. (1997) \\
\hline & Anthesis-silking interval & 6 & $1,2,5,6,8,10$ & 48 (total) & Ribaut et al. (1996) \\
\hline \multirow[t]{7}{*}{ Wheat } & $\begin{array}{l}\text { Agronomic, phonological and } \\
\text { physiological traits }\end{array}$ & 104 & $\begin{array}{l}1 \mathrm{~A}, 1 \mathrm{~B}, 1 \mathrm{D}, 2 \mathrm{~B}, 3 \mathrm{~A}, 3 \mathrm{~B}, 4 \mathrm{~A}, 4 \mathrm{~B} \\
4 \mathrm{D}, 5 \mathrm{~A}, 5 \mathrm{~B}, 6 \mathrm{~A}, 6 \mathrm{~B}, 7 \mathrm{~A}, 7 \mathrm{~B} \\
\mathrm{UA}-\mathrm{b}\end{array}$ & $11.2-33.5$ & Pinto et al. (2010) \\
\hline & Morpho-physiological traits & 110 & All 14 chromosomes & $0.8-42.4$ & Peleg et al. (2009) \\
\hline & Grain yield and growth traits & 42 & $\begin{array}{l}1 \mathrm{~A}, 1 \mathrm{~B}, 2 \mathrm{~A}, 2 \mathrm{~B}, 3 \mathrm{~A}, 3 \mathrm{~B}, 4 \mathrm{~A}, 4 \mathrm{~B} \\
5 \mathrm{~A}, 6 \mathrm{~B}, 7 \mathrm{~A} \text { and } 7 \mathrm{~B}\end{array}$ & $3.4-53.9$ & Maccaferri et al. (2008) \\
\hline & $\begin{array}{l}\text { Water-soluble carbohydrates and } \\
\text { associated traits }\end{array}$ & 48 & $\begin{array}{l}\text { All chromosomes except 2B, 3D, } \\
4 \mathrm{D}, 5 \mathrm{D} \text {, and } 6 \mathrm{D}\end{array}$ & $1.1-7.6$ & Yang et al. (2007) \\
\hline & $\begin{array}{l}\text { Grain yield and yield components } \\
\text { under drought }\end{array}$ & 1 & $4 \mathrm{AL}$ & $12.0-41.0$ & Kirigwi et al. (2007) \\
\hline & Yield and growth traits & 16 & $\begin{array}{l}1 \mathrm{~B}, 1 \mathrm{D}, 2 \mathrm{~B}, 3 \mathrm{~A}, 4 \mathrm{~A}, 4 \mathrm{~B}, 4 \mathrm{D}, 5 \mathrm{~A}, \\
5 \mathrm{~B}, 6 \mathrm{~A}, 6 \mathrm{~B}, 6 \mathrm{D}, 7 \mathrm{~A}, 7 \mathrm{~B}\end{array}$ & - & Mathews et al. (2008) \\
\hline & Stem reserves mobilization & 3 & $2 \mathrm{D}, 5 \mathrm{D}, 7 \mathrm{D}$ & $21.1-42.3$ & Salem et al. (2007) \\
\hline \multirow[t]{8}{*}{ Barley } & $\begin{array}{l}\text { Drought-related morphological and } \\
\text { physiological traits }\end{array}$ & 18 & $1 \mathrm{H}, 2 \mathrm{H}, 3 \mathrm{H}, 4 \mathrm{H}, 5 \mathrm{H}, 6 \mathrm{H}, 7 \mathrm{H}$ & $14.3-57.5$ & Chen et al. (2010) \\
\hline & $\begin{array}{l}\text { Chlorophyll and chlorophyll } \\
\text { fluorescence parameters }\end{array}$ & 5 & $1 \mathrm{H}, 2 \mathrm{H}, 4 \mathrm{H}, 6 \mathrm{H}, 7 \mathrm{H}$ & $6.2-13.6$ & Guo et al. (2008) \\
\hline & Yield and growth traits & 42 & All chromosomes & $6.5-36.9$ & von Korff et al. (2008) \\
\hline & $\begin{array}{l}\text { Drought-related morphological and } \\
\text { physiological traits }\end{array}$ & 68 & $\mathrm{IH}, 2 \mathrm{H}, 3 \mathrm{H}, 4 \mathrm{H}, 5 \mathrm{H}, 6 \mathrm{H}, 7 \mathrm{H}$ & $4.0-16.0$ & Diab et al. (2004) \\
\hline & Yield and other agronomic traits & 74 & All chromosomes & $1.4-84.8$ & Baum et al. (2003) \\
\hline & Relative water content & 6 & $2 \mathrm{H}, 5 \mathrm{H}, 6 \mathrm{H}, 7 \mathrm{H}$ & $6.8-11.5$ & Teulat et al. (2003) \\
\hline & Grain carbon isotope discrimination & 10 & $2 \mathrm{H}, 3 \mathrm{H}, 6 \mathrm{H}, 7 \mathrm{H}$ & - & Teulat et al. (2002) \\
\hline & $\begin{array}{l}\text { Osmotic adjustment }(\mathrm{OA}) \text { and } \\
\text { related traits }\end{array}$ & 22 & $1 \mathrm{H}, 2 \mathrm{H}, 4 \mathrm{H}, 5 \mathrm{H}, 7 \mathrm{H}$ & $5.0-20.0$ & Teulat et al. (2001a) \\
\hline
\end{tabular}


Table 1 continued

\begin{tabular}{|c|c|c|c|c|c|}
\hline Crop & Traits studied & $\begin{array}{l}\text { Number } \\
\text { of QTLs }\end{array}$ & $\begin{array}{l}\text { Chromosome/linkage } \\
\text { group }\end{array}$ & $\begin{array}{l}\text { Phenotypic } \\
\text { variation } \\
\text { explained } \\
\text { (PVE \%) }\end{array}$ & Reference \\
\hline & Grain yield and agronomic traits & 56 & All chromosomes & $5.7-23.6$ & Teulat et al.(2001b) \\
\hline & $\begin{array}{l}\text { Osmotic adjustment }(\mathrm{OA}) \text { and } \\
\text { related traits }\end{array}$ & 12 & $1 \mathrm{H}, 2 \mathrm{H}, 5 \mathrm{H}, 6 \mathrm{H}$ & $5.8-26.7$ & Teulat et al. (1998) \\
\hline \multirow[t]{7}{*}{ Sorghum } & Stay green & 1 (Stg2) & A & 53.5 & Sanchez et al. (2002) \\
\hline & Stay green & 10 & $\mathrm{~A}, \mathrm{C}, \mathrm{D}, \mathrm{E}, \mathrm{G}, \mathrm{H}$ & $5.1-26.3$ & Haussmann et al. (2002) \\
\hline & Stay green & 9 & $\mathrm{~A}, \mathrm{~B}, \mathrm{C}, \mathrm{D}, \mathrm{E}, \mathrm{F}, \mathrm{G}, \mathrm{J}$ & $9.9-22.6$ & Kebede et al. (2001) \\
\hline & Stay green & 8 & $\mathrm{~A}, \mathrm{D}, \mathrm{E}, \mathrm{J}$ & $9.1-32.6$ & Subudhi et al. (2000) \\
\hline & Stay green & 4 & $\mathrm{~A}, \mathrm{D}, \mathrm{J}$ & $13.0-30.0$ & Xu et al. (2000) \\
\hline & Stay green & 5 & $\mathrm{~B}, \mathrm{G}, \mathrm{I}$ & $10.7-14.1$ & Tao et al. (2000) \\
\hline & Stay green and maturity & 9 & $\mathrm{~A}, \mathrm{~B}, \mathrm{D} 2, \mathrm{G}, \mathrm{I} 1, \mathrm{I} 2, \mathrm{~J}$ & $7.7-47.5$ & Crosta et al. (1999) \\
\hline \multirow{2}{*}{$\begin{array}{l}\text { Pearl } \\
\text { millet }\end{array}$} & Grain yield and related traits & 20 & $1,2,3,4,5,6,7$ & $11.6-57.2$ & Bidinger et al. (2007) \\
\hline & $\begin{array}{l}\text { Grain yield and other physiological } \\
\text { traits }\end{array}$ & 46 & $1,2,3,4,6,7$ & $8.4-57.2$ & Yadav et al. (2002) \\
\hline \multirow[t]{5}{*}{ Soybean } & Yield and wilting & 6 & $\mathrm{D} 2, \mathrm{~F}, \mathrm{~F} 2$ & - & Monteros et al. (2006) \\
\hline & Leaf wilting & 1 & $\mathrm{~K}$ & 17.0 & Bhatnagar et al. (2005) \\
\hline & Yield & 1 & $\mathrm{C} 2$ & 7.0 & Specht et al. (2001) \\
\hline & Water use efficiency & 7 & $\mathrm{~L}$ & $8.0-14.0$ & Mian et al. (1998) \\
\hline & Water use efficiency & 5 & $\mathrm{G}, \mathrm{H}, \mathrm{J}, \mathrm{C} 1$ & $5.0-13.2$ & Mian et al. 1996) \\
\hline \multirow{2}{*}{$\begin{array}{l}\text { Common } \\
\text { bean }\end{array}$} & Yield and yield component traits & 49 & All except LG1 & $7.0-31.0$ & Blair et al. (2012) \\
\hline & Yield and yield component traits & 9 & - & - & Schneider et al. (1997a) \\
\hline \multirow[t]{2}{*}{ Tomato } & Seed germination & 4 & $1,8,9,12$ & $\begin{array}{l}\text { Major } \\
\text { effects }\end{array}$ & Foolad et al. (2003) \\
\hline & Water use efficiency & 3 & Undetermined & - & Martin et al. (1989) \\
\hline \multirow[t]{2}{*}{ Cotton } & Productivity and physiological traits & 79 & $\begin{array}{l}1,2,4,5,6,9,10,11,12,13,14 \\
15,18,20,22,25\end{array}$ & $1.7-23.7$ & Saranga et al. (2004) \\
\hline & Productivity and physiological traits & 16 & $2,3,4,5,6,7,9,14,15,18,22,25$ & $4.1-16.2$ & Saranga et al. (2001) \\
\hline
\end{tabular}

with abiotic stress tolerance including drought tolerance in crop plants is available at PLANTSTRESS site (http:// www.plantstress.com/biotech/index.asp?Flag=1). Most of the identified QTLs for drought traits explain a relatively small portion of total phenotypic variation. As a result, their direct deployment in breeding programmes through marker-assisted selection (MAS) may not be very effective.

QTL cloning for drought tolerance-related traits

In general, QTLs identified through linkage mapping-based approaches have low resolution and have been located in 10-20 cM intervals. The support interval of the QTL may also span several hundreds of genes and identifying the right candidate gene(s) with causal effect on the trait is like finding a 'needle' in the 'genomic haystack'. Therefore, to identify the causal gene(s), positional cloning of QTLs have been undertaken in several crop species (Salvi and
Tuberosa 2005; Tuberosa and Salvi 2006). QTL cloning, in general, involves the following steps: (1) delimiting the QTL region by using a large mapping population $(>1,500$ plants) derived from a cross between two NILs for the target QTL, (2) identifying the contig covering the QTL region by screening the closely linked molecular markers with a large insert library like BAC (bacterial artificial chromosome) library, (3) sequencing the contig and candidate gene identification based on sequence data and (4) validating the effect of candidate gene(s) on phenotype.

Although many reports are available on cloning of QTLs associated with different traits (see Salvi and Tuberosa 2007), there are few reports addressing QTL cloning for drought tolerance traits. For instance, a major flowering time QTL "Vgtl" associated with drought tolerance has been cloned in maize (Salvi et al. 2002, 2007). Recently, the gene encoding ATP-binding cassette (ABC) subfamily $\mathrm{G}(H v A B C G 31)$ full transporter was cloned from eibil 
mutation responsible for leaf water conservation in wild barley and rice (Chen et al. 2011). Newer genomics approaches like association mapping and next-generation sequencing (NGS) hold great promise for accelerating QTL cloning of drought tolerance-related traits. The cloning of drought tolerance QTLs provides an opportunity to validate candidate genes that can be used to develop transgenic plants, not only in the original crop species but also in other crop species.

Identification of genes associated with drought tolerance

The significant advances made in the model plant systems of major crop species provide an opportunity to identify candidate genes associated with drought tolerance. Some approaches are discussed in the following section:

\section{Candidate genes (CGs) from model plant species}

Genome sequences have recently become available for several model and major plant species (Feuillet et al. 2010). Genome annotation, molecular physiological as well as functional genomics studies undertaken in model and/or major crop species provide evidence of the candidate genes (CGs) involved in conferring drought tolerance. The CGs can be: (a) genes involved in cell protection under drought stress (e.g. proteins involved in osmotic adjustment, degradation, repairs, detoxification and structural adaptations) and/or (b) genes involved in regulation of other genes involved in the drought response (protein kinases and transcription factors such as DREB, bZIP, MYB, etc.). Knowledge of the CGs responsible for drought tolerance is useful for understanding the functional basis of drought tolerance and assists in their subsequent use, once they are validated, in molecular breeding through MAS. For instance, a set of nearly 30 important candidate genes associated with drought tolerance have been compiled by Sehgal and Yadav (2010). Validation of the CGs, an important and essential step before they can be deployed, can be undertaken using several approaches including integration with QTL maps, association mapping, expression analysis using qRT-PCR, allele mining and TILLING. Several of these approaches in relation to breeding programme applications are discussed by Varshney et al. (2005). One such example is the mapping of two CGs (OsEXP2 and EGase) involved in cell expansion within the expected intervals of QTL for root traits in rice (Zheng et al. 2003). Similarly, 16 CGs associated with drought tolerance were included in the integrated QTL and physical map of rice (Wang et al. 2005). However, candidate genes have not delivered as much as anticipated for crop breeding, especially for drought tolerance.

\section{Transcriptomics and functional genomics}

Transcriptomics and functional genomics have been used extensively in recent years to better understand the stressresponsive mechanisms in crop plants. The candidate genes associated with drought tolerance mechanisms have been identified, characterized and assessed for their transcriptome responses using whole-genome sequencing or through micro-array technologies. The generation of ESTs from either normalized or non-normalized cDNA libraries from drought-challenged tissues of drought-responsive genotypes is one of the most common approaches for isolation of drought-responsive candidate genes. A large number of drought-responsive genes have been generated in several crop species. In rice, normalized cDNA libraries from drought-stressed seedlings led to the identification of novel genes that were abundantly expressed under drought stress and so far dozens of rice genes have been identified as drought responsive (Reddy et al. 2002; Hadiarto and Tran 2011 and references therein). Similarly, a survey of all the publicly available ESTs in various cereal crops including barley, maize, rice and wheat has led to the identification of drought stress-responsive genes in these species (Sreenivasulu et al. 2004, 2007; Kathiresana et al. 2006). In case of chickpea, twofold transcriptional changes were observed for 109 genes under drought (Mantri et al. 2007) and >220 (70 \%) drought-tolerant unique ESTs were identified by Jain and Chattopadhyay (2010). In addition, 11,904 drought-responsive ESTs were generated earlier at ICRISAT for chickpea (Varshney et al. 2009a). This study was further extended by the National Research Centre on Plant Biotechnology (NRCPB) in India and 5,494 highquality drought-responsive ESTs were isolated using suppression subtraction hybridization ( $\mathrm{SSH}$ ) of droughtchallenged root and shoot tissues (Deokar et al. 2011). Such studies provide an important resource for marker development and also act as resource for the identification and selection of candidate genes (both up- and down-regulated) associated with drought tolerance. Although bioinformatics analysis (e.g. BLASTX) of such ESTs can help to identify the most promising EST/gene(s), it is essential to prove the function of the most promising genes using wet laboratory experiments such as qRT-PCR.

Another approach to identify candidate genes is transcript profiling that involves analysis of differential gene expression in the given tissue at different time points after exposure of the plant to drought stress or between droughttolerant and susceptible genotypes (Hazen et al. 2003; Shinozaki et al. 2003; Micheletto et al. 2007; Hampton et al. 2010). However, it is important to target the right tissue and the precise stage of tissue in addition to the dynamics (i.e. timing and intensity) of the stress treatment imposed to mimic drought conditions for isolation of RNA 
for use in transcriptomics studies (Talamè et al. 2007). Instead of using genotypes with different genetic background, near-isogenic lines (NILs), which differ only in the target trait, are the ideal genetic material that ensures differentially expressed genes are linked to the trait and not to the genetic background. More recently, it was demonstrated that miRNAs are also involved in drought stress response/tolerance in crop plants including rice (Zhou et al. 2010) and soybean (Kulcheski et al. 2011) and their validation revealed their possible involvement in drought tolerance (Kulcheski et al. 2011).

Several platforms have become available for transcript profiling: (a) PCR-based differential display PCR (DDRTPCR) analysis (Liang and Pardee 1992), (b) cDNAAmplified Fragment Length Polymorphism (cDNA-AFLP) analysis (Bachem et al. 1996), (c) cDNA and oligonucleotide microarrays (Sreenivasulu et al. 2010) and (d) digital expression analysis based on counts of ESTs (Varshney et al. 2009a; Raju et al. 2010). SuperSAGE (Matsumura et al. 2003, 2010), an improved version of the serial analysis of gene expression (SAGE) technique, has been also successfully applied in several crop plants including chickpea for expression analysis of $\sim 80,000$ transcripts from unstressed and drought-stressed roots (Molina et al. 2008). However, with the advent of NGS technology (Varshney et al. 2009b), the sequence-based transcriptome analysis is in many ways considered superior to microarrays in orphan crops where genome sequence information is lacking, since the sequencing-based method is real time, digital and highly accurate. Therefore, it is anticipated that microarrays may soon be replaced by sequencing-based digital gene expression analysis (Shendure 2008; Varshney et al. 2009b). The application of NGS technologies to gene expression analysis has catalysed the development of techniques like Digital Gene Expression TAG (DGE-TAG), DeepSAGE (Nielsen et al. 2006, 2008) and RNA-Seq (Marioni et al. 2008; Nagalakshmi et al. 2008). RNA-seq based on NGS technologies has several advantages for examining transcriptome fine structure including detection of allele-specific expression and splice junctions (Malone and Oliver 2011) and may allow direct high-throughput sequencing of RNA from the stress (e.g. drought)-challenged tissues of different genotypes. Such transcript profiling (including RNA-seq) based on droughttolerant and drought-sensitive genotypes can identify candidate genes associated with drought tolerance that can be used as genic molecular markers (GMMs) and integrated into genetic/QTL maps (Hiremath et al. 2011). It is possible that some candidate genes identified as above may be associated with QTLs for drought tolerance traits. In such cases, a genetical genomics approach that involves quantitative analysis of transcript profiling of the candidate genes can provide the e(xpression) QTLs for drought tolerance-related traits (Varshney et al. 2005). In case eQTLs are found in the cis-condition, then the candidate gene-based molecular markers should act as the functional and diagnostic markers for the respective traits (Potokina et al. 2008). It is anticipated that NGS-based transcript profiling should be routinely used for major crop species in the identification of candidate genes for drought tolerance and for subsequent use in genetical genomics or molecular breeding.

\section{Modern breeding approaches for developing superior germplasm for drought tolerance}

Once the candidate genes or markers associated with QTLs for drought tolerance are identified, the next step is their deployment in breeding practices. Some of these approaches are discussed below.

\section{Marker-assisted backcrossing (MABC)}

When the QTLs identified for drought tolerance traits contribute higher phenotypic variation, they are considered major QTLs. These QTLs, after validation in desired germplasm, can be used for introgressing drought tolerance from the donor genotypes (generally used for identification of the QTL for the trait) into elite, less drought-tolerant cultivars or breeding lines (recipient parents) without transfer of undesirable or deleterious genes from the donors (linkage drag). The process is commonly referred to as marker-assisted backcrossing (MABC). Superior lines or cultivars are developed that contain only the major gene/ QTL from the donor parent, while retaining the whole genome of the recurrent parent (Hospital 2003; Varshney and Dubey 2009; Gupta et al. 2010). Although MABC has been used extensively for introgressing resistance to biotic stresses, only a few reports are available on the use of MABC to develop the superior lines/varieties for drought tolerance (Table 2). For instance, MABC has been used to introgress root trait QTLs in the elite rice cultivars IR64 and Kalinga III (Shen et al. 2001; Steele et al. 2006). By using these MABC products, a variety namely "Birsa Vikas Dhan 111 (PY 84)" was developed and released in Jharkhand State of India (Steele et al. 2007). In this example, MABC was used to transfer multiple QTLs for improved root growth under drought conditions. Similar work was done in maize to introgress favourable alleles at five target regions that influence the expression of yield components, flowering traits (including anthesis-silking interval (ASI)) and increased grain yield under water-limited conditions (see Ribaut and Ragot 2007). Backcrossderived lines differing in the parental alleles (Os420 and IABO78) at a major QTL (root-ABAl) have also been 
developed in maize (Tuberosa et al. 1998; Sanguineti et al. 1999) and a very strong and consistent effect of this QTL on leaf ABA concentration (L-ABA) across different water regimes has been confirmed in subsequent studies (Giuliani et al. 2005; Landi et al. 2005, 2007). Field evaluation conducted under well-watered and water-stressed conditions in two consecutive seasons indicated that each pair of root-ABAl backcross-derived near isogenic lines differed significantly and markedly for L-ABA, thus confirming the effectiveness of MAS (Landi et al. 2005). Similarly, a major QTL for improved grain yield in pearl millet under terminal drought stress when transferred into a droughtsensitive genotype showed a consistent grain yield advantage (Serraj et al. 2005). Key reports on MABC for drought tolerance have been compiled in Table 2 .

The relatively low success of MABC for improving drought tolerance can be attributed to the complex nature of drought. In many instances, the expression of drought tolerance is controlled by minor main-effect QTLs or epistatic QTLs. For instance, QTLs with $\sim 10 \%$ phenotypic variation for drought tolerance have been identified in maize (Xu et al. 2009), groundnut (Ravi et al. 2011), etc. These studies highlight the need to transfer several QTLs/ genes to achieve a significant impact, assuming additive variance, and this may require unmanageable population sizes (Ribaut et al. 2010).

\section{Marker-assisted recurrent selection (MARS)}

To overcome the limitations of MABC, particularly when multiple QTLs control the expression of a complex trait, the MARS approach, which involves intermating selected individuals in each selection cycle, has been recommended (Eathington et al. 2007; Ribaut and Ragot 2007; Bernardo 2008). It generally involves the use of an $F_{2}$ base population, and can be used in self-pollinated crops like wheat, barley and chickpea for developing pure lines with superior per se performance (for more details, see Bernardo 2008). MARS has the additional advantage of overcoming the limitation of inadequate improvement in the frequency of superior alleles in $\mathrm{F}_{2}$ enrichment, since MAS is practised in each cycle following intermating to improve the frequency of favourable alleles (Eathington et al. 2007). The successful use of MARS has been reported in sweet corn (Edwards and Jonson 1994), sunflower and soybean
(Eathington et al. 2007). In case of wheat, MARS for water use efficiency is being exercised under an Indo-Australian project involving partners from DWR, Karnal, PAU Ludhiana, IARI, New Delhi and Australia. Generation Challenge Programme (GCP) also launched a challenge initiative to improve heat/drought tolerance in wheat through MARS approach involving the Indian Agricultural Research Institute (IARI), New Delhi, India, Chinese Academy of Agricultural Sciences (CAAS), China, and partners from Australia (http://www.generationcp.org/ ci_feb_2010_launch_meeting_feature). Similar MARS breeding programmes are being conducted at several other international institutes including ICRISAT, the French Centre for International Agricultural Research (CIRAD) and University of California-Riverside, USA for improving drought tolerance in chickpea, sorghum and cowpea, respectively (see Kulwal et al. 2011).

\section{Genome-wide selection (GWS)}

Genome-wide selection (GWS) or genomic selection (GS) is another important approach to develop superior germplasm lines with overall excellent performance in a target environment.

Genome-wide marker genotyping is used for GWS rather than selected markers showing significant associations (as in case of MARS) with the traits of interest. In summary, individuals in a phenotyped population (generally referred to as the 'training population') are genotyped using genome-wide markers and breeding values of alternative alleles of all the markers are fitted as random effects in a linear model. Individuals in subsequent recurrent selection generations are then selected based purely on the sum of those breeding values [genomic estimated breeding value (GEBV); Meuwissen et al. 2001]. Therefore, GWS reduces the frequency of phenotyping and similarly also increases annual gains from selection by reducing cycle time (Rutkoski et al. 2010). Several groups have recently started exploring the GWS approach in both self- and cross-pollinated crops with some modifications for both types of crops (Bernardo 2010). The success of the GWS approach is dependent on the availability of a diverse and representative training population. Furthermore, the phenotyping of the training population is crucial and additional lines should be integrated over time to increase the

Table 2 Some examples of marker-assisted selection (MAS) for drought tolerance in crop plants

\begin{tabular}{llll}
\hline Crop & Trait improved & No. of genes/QTL transferred & Reference \\
\hline Rice & Yield and grain quality under drought & Multiple QTL & Steele et al. (2006, 2007) \\
Cotton & Drought tolerance-related traits & 7 QTLs & Levi et al. (2009) \\
Common bean & Drought tolerance-related traits & Multiple QTL (9 RAPD markers) & Schneider et al. (1997b) \\
\hline
\end{tabular}


effectiveness and relevance of the gene effect estimates. This approach has been recently used to improve durable stem rust resistance in wheat (Rutkoski et al. 2010) and eventually could be systematically explored to bring different components of multigenic drought tolerance using the GWS approach.

\section{Lessons learnt and future outlook}

It is evident that precise phenotyping is essential to screen larger core collection/mapping population for identifying the most appropriate QTL and candidate genes for use in plant breeding. A number of phenotyping approaches are available and this area of research is currently referred to as 'phenomics'. Nevertheless, re-integration of the pieces of the 'phenomics' puzzle into a comprehensive and relevant crop improvement framework of 'seed yield stability' will involve crop modelling (Tardieu and Tuberosa 2010). The combination of phenomics and modelling offers great potential to rapidly assess the value of certain traits on plant performance. The use of models to understand geneto-phenotype relationships provides an efficient platform for a new and creative interaction between geneticsgenomics and crop physiology (Edmeades et al. 2004). To meet the real-world challenge of increased crop production, the information available from functional genomics and systems biology needs to be integrated at the crop level; thereby, crop physiology will have a fundamental role in achieving this goal. A new generation of crop models combined with systems biology studies should enable us to significantly narrow the gap between genes and complex phenotypes by predicting the field performance of crop genotypes (Yin et al. 2004). Crop models will significantly contribute to higher level of integration by directly linking physiological processes to complex crop phenotypes within the scope of source-sink relationships. Similarly, recent advances in genomics make it possible to not only conduct large-scale and high-throughput marker genotyping, but also sequence or re-sequence the genomes of germplasm collections, thus facilitating the identification of QTLs and candidate genes associated with drought tolerance. While commonly used MABC has not been very effective in developing superior lines for drought tolerance, modern breeding approaches such as MARS and GWS are powerful tools for pyramiding multiple QTLs for drought tolerance or introgressing multiple complex traits such as heat tolerance in addition to drought tolerance.

In summary, it is essential to integrate crop physiology, genomics and breeding approaches to dissect complex drought tolerance traits, understand the molecular basis of drought tolerance and develop the next-generation crops for our changing climate. Although work is ongoing in some major crops, it is anticipated that integrated physiology, genomics and breeding approaches will be initiated/ accelerated in the so-called orphan crops that are important for food security in many developing countries.

Acknowledgments RKV is thankful to the Centre of Excellence (CoE) grant from the Department of Biotechnology (DBT) of Government of India, Theme Leader Discretionary Grant from CGIARGeneration Challenge Programme (GCP), and Tropical Legume I, Phase II Project of GCP and Bill and Melinda Gates Foundation dealing with integrated genomics, physiology and breeding research for crop improvement at ICRISAT.

Open Access This article is distributed under the terms of the Creative Commons Attribution License which permits any use, distribution, and reproduction in any medium, provided the original author(s) and the source are credited.

\section{References}

Ashraf M (2010) Inducing drought tolerance in plants: recent advances. Biotechnol Adv 28:169-183

Babu CR, Nguyen BD, Chamarerk V (2003) Genetic analysis of drought resistance in rice by molecular markers: association between secondary traits and field performance. Crop Sci 43:1457-1469

Bachem CWB, van der Hoeven RS, De Bruijn SM, Vreugdenhil D, Zabeau M, Visser RGF (1996) Visualization of differential gene expression using a novel method of RNA fingerprinting based on AFLP: analysis of gene expression during potato tuber development. Plant J 9:745-753

Barkley NA, Wang ML (2008) Application of TILLING and EcoTILLING as reverse genetic approaches to elucidate the function of genes in plants and animals. Curr Genomics 9:212-226

Barnabas B, Jager K, Feher A (2008) The effect of drought and heat stress on reproductive processes in cereals. Plant Cell Environ 31:11-38

Bartels D, Sunkar R (2005) Drought and salt tolerance in plants. Crit Rev Plant Sci 24:23-58

Baum M, Grando S, Backes G (2003) QTLs for agronomic traits in the Mediterranean environment identified in recombinant inbred lines of the cross 'Arta' $\times H$. spontaneum 41-1. Theor Appl Genet 107:1215-1225

Baum M, Von Korff M, Guo P, Lakew B, Udupa SM, Sayed H, Choumane W, Grando S, Ceccarelli S (2007) Molecular approaches and breeding strategies for drought tolerance in barley. In: Varshney RK, Tuberosa R (eds) Genomics assisted crop improvement, vol 2., Genomics applications in cropsSpringer, The Netherlands, pp 51-80

Bernardo R (2008) Molecular markers and selection for complex traits in plants: learning from the last 20 years. Crop Sci 48:1649-1664

Bernardo R (2010) Genome wide selection with minimal crossing in self-pollinated crops. Crop Sci 50:624-627

Bernier J, Kumar A, Venuprasad R, Spaner D, Atlin G (2007) A large-effect QTL for grain yield under reproductive-stage drought stress in upland rice. Crop Sci 47:507-518

Bernier J, Atlin GN, Serraj R, Kumar A, Spaner D (2008) Breeding upland rice for drought resistance. J Sci Food Agric 88:927-939

Bernier J, Serraj R, Kumar A, Venuprasad R, Impa S, Gowda V, Oane R, Spaner D, Atlin G (2009) The large-effect drought-resistance 
QTL qtl12.1 increases water uptake in upland rice. Field Crops Res 110:139-146

Bhatnagar S, King CA, Purcell L, Ray JD (2005) Identification and mapping of quantitative trait loci associated with crop responses to water-deficit stress in soybean [Glycine $\max$ (L.) Merr.]. The ASA-CSSA-SSSA International annual meeting poster abstract, November 6-10, 2005, Salt Lake City, UT, USA

Bhatnagar-Mathur P, Vadez V, Sharma KK (2008) Transgenic approaches for abiotic stress tolerance in plants: retrospect and prospects. Plant Cell Rep 27:411-424

Bidinger FR, Napolean T, Hash CT (2007) Quantitative trait loci for grain yield in pearl millet under variable post flowering moisture conditions. Crop Sci 47:969-980

Blair MW, Galeano CH, Tovar E, Torres MCM, Castrillón AV, Beebe SE, Rao IM (2012) Development of a Mesoamerican intra-genepool genetic map for quantitative trait loci detection in a drought tolerant $\times$ susceptible common bean (Phaseolus vulgaris $\mathrm{L}$.) cross. Mol Breeding 29:71-88

Blum A (1998) Improving wheat grain filling under stress by stem reserve mobilisation. Euphytica 100:77-83

Blum A (2009) Effective use of water (EUW) and not water use efficiency (WUE) is the target of crop yield improvement under drought stress. Field Crop Res 112:119-123

Braun HJ, Atlin G, Payne T (2010) Multi-location testing as a tool to identify plant response to global climate change. In: Reynolds MP (ed) Climate change and crop production. CABI Publishers, Wallingford, pp 115-138

Bressan R, Bohnert H, Zhu JK (2009) Abiotic stress tolerance: from gene discovery in model organisms to crop improvement. Mol Plant 2:1-2

Cattivelli L, Rizza F, Badeck FW, Mazzucotelli E, Mastrangelo AM, Francia E, Mare C, Tondelli A, Stanca AM (2008) Drought tolerance improvement in crop plants: an integrated view from breeding to genomics. Field Crops Res 105:1-14

Chaerle L, van der Straeten D (2000) Imaging techniques and the early detection of plant stress. Trends Plant Sci 5:495-501

Chamarthi SK, Kumar A, Vuong T, Blair MW, Gaur PM, Nguyen HT, Varshney RK (2011) Trait mapping and molecular Breeding in legumes: concepts and examples in soybean, common bean and chickpea. In: Pratap A, Kumar J (eds) Biology and breeding of food legumes. CABI International, Oxfordshire, UK (in press)

Chapman SC (2008) Use of crop models to understand genotype by environment interactions for drought in real-world and simulated plant breeding trials. Euphytica 161:195-208

Charron AJ, Quatrano RS (2009) Between a rock and a dry place: the water-stressed moss. Mol Plant 2:478-486

Chen G, Krugman T, Fahima T, Chen K, Hu Y, Roder M, Nevo E, Korol A (2010) Chromosomal regions controlling seedling drought resistance in Israeli wild barley, Hordeum spontaneum C. Koch. Genet Resour Crop Evol 57:85-99

Chen G, Komatsuda T, Ma JF, Nawrath C, Pourkheirandish M, Tagiri A, Hu YG, Sameri M, Li X, Zhao X, Liu Y, Li C, Ma X, Wang A, Nair S, Wang N, Miyao A, Sakuma S, Yamaji N, Zheng X, Nevo E (2011) An ATP-binding cassette subfamily G full transporter is essential for the retention of leaf water in both wild barley and rice. Proc Natl Acad Sci USA 108:12354-12359

Collins NC, Tardieu F, Tuberosa R (2008) Quantitative trait loci and crop performance under abiotic stress: Where do we stand? Plant Physiol 147:469-486

Courtois B, Shen L, Petalcorin W, Carandang S, Mauleon R, Li Z (2003) Locating QTLs controlling constitutive root traits in the rice population IAC $165 \times$ Co39. Euphytica 134:335-345

Deokar AA, Kondawar V, Jain PK, Karuppayil SM, Raju NL, Vadez V, Varshney RK, Srinivasan R (2011) Comparative analysis of expressed sequence tags (ESTs) between drought-tolerant and susceptible genotypes of chickpea under terminal drought stress. BMC Plant Biol 11:70

Diab AA, Teulat-Merah B, This D, Ozturk NZ, Benscher D, Sorrells ME (2004) Identification of drought-inducible genes and differentially expressed sequence tags in barley. Theor Appl Genet 109:1417-1425

Eathington SR, Crosbie TM, Edwards MD, Reiter RS, Bull JK (2007) Molecular markers in a commercial breeding program. Crop Sci 47:S154-S163

Edmeades GO, McMaster GS, White JW (2004) Genomics and the physiologist: bridging the gap between genes and crop response. Field Crops Res 90:5-18

Edwards M, Johnson L (1994) RFLPs for rapid recurrent selection. In: Joint plant breeding symposium series of CSSA and ASHA, 5-6 Aug, Corvallis, Alexandria, VA

Farre G, Ramessar K, Twyman RM, Capell T, Christou P (2010) The humanitarian impact of plant biotechnology: recent breakthroughs vs bottlenecks for adoption. Curr Opin Plant Biol $13: 219-225$

Feuillet C, Leach JE, Rogers J, Schnable PS, Eversole K (2010) Crop genome sequencing: lessons and rationales. Trends Plant Sci 16:77-88

Fleury D, Jefferies S, Kuchel H, Langridge P (2010) Genetic and genomic tools to improve drought tolerance in wheat. J Exp Bot 61:3211-3222

Foolad MR, Zhang LP, Subbiah P (2003) Genetics of drought tolerance during seed germination in tomato: inheritance and QTL mapping. Genome 46:536-545

Giuliani S, Sanguineti MC, Tuberosa R (2005) Root-ABA1, a major constitutive QTL, affects maize root architecture and leaf ABA concentration at different water regimes. J Exp Bot 56:3061-3070

Gray SB, Dermody O, DeLucia EH (2010) Spectral reflectance from a soybean canopy exposed to elevated $\mathrm{CO}_{2}$ and $\mathrm{O}_{3}$. J Exp Bot 61:4413-4422

Guo P, Baum M, Varshney R, Graner A, Grando S, Ceccarelli S (2008) QTLs for chlorophyll and chlorophyll fluorescence parameters in barley under post-flowering drought. Euphytica 163:203-214

Gupta PK, Kumar J, Mir RR, Kumar A (2010) Marker assisted selection as a component of conventional plant breeding. Plant Breed Rev 33:145-217

Gutierrez M, Reynolds MP, Klatt AR (2010) Association of water spectral indices with plant and soil water relations in contrasting wheat genotypes. J Exp Bot 61:3291-3303

Hacisalihoglu G, Larbi B, Settles AM (2010) Near-infrared reflectance spectroscopy predicts protein, starch, and seed weight in intact seeds of common bean (Phaseolus vulgaris L.). J Agric Food Chem 58:702-706

Hadiarto T, Tran L-SP (2011) Progress studies of drought-responsive genes in rice. Plant Cell Rep 30:297-310

Hampton M, Xu WW, Kram BW, Chambers EM, Ehrnriter JS, Gralewski JH, Joyal T, Carter CJ (2010) Identification of differential gene expression in Brassica rapa nectaries through expressed sequence tag analysis. PLoS ONE 5:e8782

Haussmann BIG, Mahalakshmi V, Reddy BVS, Seetharama N, Hash CT, Geiger HH (2002) QTL mapping of stay-green in two sorghum recombinant inbred populations. Theor Appl Genet 106:133-142

Hazen SP, Wu Y, Kreps JA (2003) Gene expression profiling of plant responses to abiotic stress. Funct Integr Genomic 3:105-111

Held IM, Delworth TL, Lu J, Findell KL, Knutson TR (2005) Simulation of Sahel drought in the 20th and 21st centuries. Proc Natl Acad Sci USA 102:17891-17896

Hiremath PJ, Farmer A, Cannon SB, Woodward J, Kudapa HB, Tuteja R, Kumar A, Prakash AB, Mulaosmanovic B, Gujaria N, 
Krishnamurthy L, Gaur PM, KaviKishor PB, Shah T, Srinivasan R, Lohse M, Xiao Y, Town CD, Cook DR, May GD, Varshney RK (2011) Large-scale transcriptome analysis in chickpea (Cicer arietinum L.), an orphan legume crop of the semi-arid tropics of Asia and Africa. Plant Biotechnol J 9:922-931

Hospital F (2003) Marker-assisted breeding. In: Newbury HJ (ed) Plant molecular breeding. Blackwell Publishing, Carlton, pp 30-56

Intergovernmental Panel on Climate Change (IPCC) (2007) In: Pachauri RK, Reisinger A (eds) Climate change 2007 synthesis report. IPCC, Geneva

Ivandic V, Thomas WTB, Nevo E, Zhang Z, Forster BP (2003) Associations of simple sequence repeats with quantitative trait variation including biotic and abiotic stress tolerance in Hordeum spontaneum. Plant Breed 122:300-304

Jahnke S, Menzel MI, van Dusschoten D, Roeb GW, Bühler J, Minwuyelet S, Blümler P, Temperton VM, Hombach T, Streun M, Beer S, Khodaverdi M, Ziemons K, Coenen HH, Schurr U (2009) Combined MRI-PET dissects dynamic changes in plant structures and function. Plant J 59:634-644

Jain D, Chattopadhyay D (2010) Analysis of gene expression in response to water deficit of chickpea (Cicer arietinum L.) varieties differing in drought tolerance. BMC Plant Biol 10:24

Jones HG (2004) Irrigation scheduling: advantages and pitfalls of plant-based methods. J Exp Bot 55:2427-2436

Jones HG (2007) Monitoring plant and soil water status: established and novel methods revisited and their relevance to studies of drought tolerance. J Exp Bot 58:119-130

Jones HG, Serraj R, Loveys BR, Xiong L, Wheaton A, Price AH (2009) Thermal infrared imaging of crop canopies for the remote diagnosis and quantification of plant responses to water stress in the field. Func Plant Biol 36:978-989

Kashiwagi J, Krishnamurthy L, Upadhyaya HD, Krishna H, Chandra S, Vadez V, Serraj R (2005) Genetic variability of droughtavoidance root traits in the mini-core germplasm collection of chickpea (Cicer arietinum L.). Euphytica 146:213-222

Kathiresana A, Lafittea HR, Chena J, Mansuetoa L, Bruskiewicha R, Bennetta J (2006) Gene expression microarrays and their application in drought stress research. Field Crops Res 97:101-110

Kato Y, Hirotsu S, Nemoto K, Yamagishi J (2008) Identification of QTLs controlling rice drought tolerance at seedling stage in hydroponic culture. Euphytica 160:423-430

Kebede H, Subudhi PK, Rosenow DT, Nguyen HT (2001) Quantitative trait loci influencing drought tolerance in grain sorghum (Sorghum bicolor L. Moench). Theor Appl Genet 103:266-276

Kirigwi FM, Ginkel MV, Brown-Guedira G, Gill BS, Paulsen GM, Fritz AK (2007) Markers associated with a QTL for grain yield in wheat under drought. Mol Breed 20:401-413

Kulcheski FR, de Oliveira LFV, Molina LG, Almerão MP, Rodrigues FA, Marcolino J, Barbosa JF, Stolf-Moreira R, Nepomuceno AL, Marcelino-Guimarães FC, Abdelnoor RV, Nascimento LC, Carazzolle MF, Pereira GAG, Margis R (2011) Identification of novel soybean microRNAs involved in abiotic and biotic stresses. BMC Genomics 12:307

Kulwal PL, Thudi M, Varshney RK (2011) Genomics interventions in crop breeding for sustainable agriculture. In: Meyers RA (ed) Encyclopedia of sustainability science and technology, Springer, New York. doi:10.1007/978-1-4419-0851-3

Lanceras JC, Pantuwan GP, Jongdee B, Toojinda T (2004) Quantitative trait loci associated with drought tolerance at reproductive stage in rice. Plant Physiol 135:384-399

Landi P, Sanguineti MC, Salvi S (2005) Validation and characterization of a major QTL affecting leaf ABA concentration in maize. Mol Breed 15:291-303

Landi P, Sanguineti MC, Liu C, Li Y, Wang TY, Giuliani S, Bellotti M, Salvi S, Tuberosa R (2007) Root-ABAl QTL affects root lodging, grain yield, and other agronomic traits in maize grown under well-watered and water-stressed conditions. J Exp Bot 5:319-326

Leung H (2008) Stressed genomics-bringing relief to rice fields. Curr Opin Plant Biol 11:201-208

Levi A, Paterson AH, Barak V, Yakir D, Wang B, Chee PW, Saranga Y (2009) Field evaluation of cotton near-isogenic lines introgressed with QTLs for productivity and drought related traits. Mol Breed 23:179-195

Liang P, Pardee AB (1992) Differential display of eukaryotic messenger RNA by means of the polymerase chain reaction. Science 257:967-971

Li-Feng L, Hong-Liang Z, Ping M (2007) Construction and evaluation of near-isogenic lines for major QTLs of basal root thickness and 1000-grain weight in lowland and upland rice. Chin J Agric Biotechnol 4:199-205

Lilley JM, Ludlow MM, McCouch SR, O'Toole JC (1996) Locating QTL for osmotic adjustment and dehydration tolerance in rice. J Exp Bot 47:1427-1436

Lobell DB, Schlenker W, Costa-Roberts J (2011) Climate trends and global crop production since 1980. Science 333:616-620

Lua Y, Zhangc S, Shah T, Xiec C, Haoc Z, Lic X, Farkharib M, Ribaut JM, Caoa M, Ronga T, Xu Y (2010) Joint linkagelinkage disequilibrium mapping is a powerful approach to detecting quantitative trait loci underlying drought tolerance in maize. Proc Natl Acad Sci USA 107:19585-19590

Luo LJ (2010) Breeding for water-saving and drought-resistance rice (WDR) in China. J Exp Bot 61:3509-3517

Maccaferri M, Sanguineti MC, Corneti S, Ortega JL, Salem MB, Bort J, DeAmbrogio E, del Moral LF, Demontis A, El-Ahmed A, Maalouf F, Machlab H, Martos V, Moragues M, Motawaj J, Nachit M, Nserallah N, Ouabbou H, Royo C, Slama A, Tuberosa R (2008) Quantitative trait loci for grain yield and adaptation of durum wheat (Triticum durum Desf) across a wide range of water availability. Genetics 178:489-511

Maccaferri M, Sanguineti MC, Demontis A, El-Ahmed A, del Moral LG, Maalouf F, Nachit M, Nserallah N, Ouabbou H, Rhouma S, Royo C, Villegas D, Tuberosa R (2011) Association mapping in durum wheat grown across a broad range of water regimes. J Exp Bot 62:409-438

Maggio A, Zhu JK, Hasegawa PM, Bressan RA (2006) Osmogenetics: Aristotle to Arabidopsis. Plant Cell 18:1542-1557

Malone JH, Oliver B (2011) Microarrays, deep sequencing and the true measure of the transcriptome. BMC Biol 9:34

Manavalan LP, Guttikonda SK, Tran LS, Nguyen HT (2009) Physiological and molecular approaches to improve drought resistance in soybean. Plant Cell Physiol 50:1260-1276

Mantri NL, Ford R, Coram TE, Pang ECK (2007) Transcriptional profiling of chickpea genes differentially regulated in response to high-salinity, cold and drought. BMC Genomics 8:303

Marioni JC, Mason CE, Mane SM, Stephens M, Gilad Y (2008) RNA-seq: an assessment of technical reproducibility and comparison with gene expression arrays. Genome Res 18:1509-1517

Martin B, Nienhuis J, King G, Schaefer A (1989) Restriction fragment length polymorphisms associated with water use efficiency in tomato. Science 243:1725-1728

Mathews KL, Malosetti M, Chapman S, McIntyre L, Reynolds M, Shorter R, van Eeuwijk F (2008) Multi-environment QTL mixed models for drought stress adaptation in wheat. Theor Appl Genet 117:1077-1109

Matsumura H, Reich S, Ito A, Saitoh H, Kamoun S, Winter P, Kahl G, Reuter M, Krüger DH, Terauchi R (2003) Gene expression analysis of plant host-pathogen interactions by SuperSAGE. Proc Natl Acad Sci USA 100:15718-15723

Matsumura H, Yoshida K, Luo S, Kimura E, Fujibe T, Albertyn Z, Barrero RA, Krüger DH, Kahl G, Schroth GP, Terauchi R (2010) 
High-throughput SuperSAGE for digital gene expression analysis of multiple samples using next generation sequencing. PLoS ONE 5:e12010

Melkus G, Rolletschek H, Fuchs J, Radchuk V, Grafahrend-Belau E, Sreenivasulu N, Rutten T, Weier D, Heinzel N, Schreiber F, Altmann T, Jakob PM, Borisjuk L (2011) Dynamic (13) C/(1) H NMR imaging uncovers sugar allocation in the living seed. Plant Biotechnol J 9:1022-1037

Merlot S, Mustilli AC, Genty B, North H, Lefebvre V, Sotta B, Vavasseur A, Giraudat J (2002) Use of infrared thermal imaging to isolate Arabidopsis mutants defective in stomatal regulation. Plant J 30:601-609

Messmer R, Fracheboud Y, Bänziger M, Vargas M, Stamp P, Ribaut JM (2009) Drought stress and tropical maize: QTL-by-environment interactions and stability of QTLs across environments for yield components and secondary traits. Theor Appl Genet 119:913-930

Meuwissen T, Hayes BJ, Goddard ME (2001) Prediction of total genetic value using genome-wide dense marker maps. Genetics 157:1819-1829

Mian MAR, Mailey MA, Ashley DA, Wells R, Carter TE, Parrot WA (1996) Molecular markers associated with water use efficiency and leaf ash in soybean. Crop Sci 36:1252-1257

Mian MAR, Ashley DA, Boerma HR (1998) An additional QTL for water use efficiency in soybean. Crop Sci 38:390-393

Micheletto S, Rodriguez-Uribe L, Hernandeza R, Richinsa RD, Currya J, O'Connell MA (2007) Comparative transcript profiling in roots of Phaseolus acutifolius and P. vulgaris under water deficit stress. Plant Sci 173:510-520

Mittler R, Blumwald E (2010) Genetic engineering for modern agriculture: challenges and perspectives. Ann Rev Plant Biol $61: 443-462$

Molina C, Rotter B, Horres R, Udupa SM, Besser B, Bellarmino L, Baum M, Matsumura H, Terauchi R, Kahl G, Winter P (2008) SuperSAGE: the drought stress-responsive transcriptome of chickpea roots. BMC Genomics 9:553

Monteros MJ, Lee G, Missaoui AM, Carter TE, Boerma HR (2006) Identification and confirmation of QTL conditioning drought tolerance in Nepalese soybean PI471938. In: The 11th Biennial conference on the molecular and cellular biology of the soybean, August 5-8, Lincoln, Nebraska

Montes JM, Melchinger AE, Reif JC (2007) Novel throughput phenotyping platforms in plant genetic studies. Trends Plant Sci 12:433-436

Myles S, Peiffer J, Brown PJ, Ersoz ES, Zhang Z, Costich DE, Buckler ES (2009) Association mapping: critical considerations shift from genotyping to experimental design. Plant Cell 21:2194-2202

Nagalakshmi U, Wang Z, Waern K, Shou C, Raha D, Gerstein M, Snyder M (2008) The transcriptional landscape of the yeast genome defined by RNA sequencing. Science 320:1344-1349

Neuberger T, Sreenivasulu N, Rokitta M, Rolletschek H, Göbel C, Rutten T, Radchuk V, Feussner I, Wobus U, Jakob P, Webb A, Borisjuk L (2008) Quantitative imaging of oil storage in developing crop seeds. Plant Biotechnol J 6:31-45

Nielsen KL, Høgh AL, Emmersen J (2006) Deep SAGE—digital transcriptomics with high sensitivity, simple experimental protocol and multiplexing of samples. Nucleic Acids Res 34:e133

Nielsen KL, Petersen AH, Emmersen J (2008) DeepSAGE: Tagbased transcriptome analysis beyond microarrays. In: Janitz M (ed) Next-generation genome sequencing: towards personalized medicine. WILEYVCH Verlag GmbH \& Co. KGaA, Weinheim, pp 229-244

Passioura JB (1977) Grain yield, harvest index, and water use of wheat. J Aust Inst Agric Sci 43:117-120
Passioura JB (2010) Scaling up: the essence of effective agricultural research. Funct Plant Biol 37:585-591

Peleg Z, Fahima T, Krugman T, Abbo S, Yakir D, Korol AB, Saranga $Y$ (2009) Genomic dissection of drought resistance in durum wheat $\times$ wild emmer wheat recombinant inbreed line population. Plant Cell Environ 32:758-779

Pellegrino A, Lebon E, Voltz M, Werry J (2007) Relationships between plant and soil water status in vine (Vitis vinifera L.). Plant Soil 266:129-142

Ping M, Zichao L, Chunping L, Hongliang Z, Changming W, Chen L, Xiangkun W (2003) QTL mapping of the root traits and their correlation analysis with drought resistance using DH lines from paddy and upland rice cross. Chin Sci Bull 48:2718-2724

Pinto RS, Reynolds MP, Mathews KL, McIntyre CL, OlivaresVillegas JJ, Chapman SC (2010) Heat and drought adaptive QTL in a wheat population designed to minimize confounding agronomic effects. Theor Appl Genet 121:1001-1021

Potokina E, Druka A, Luo Z, Wise R, Waugh R, Kearsey M (2008) Gene expression quantitative trait locus analysis of 16000 barley genes reveals a complex pattern of genome-wide transcriptional regulation. Plant J 53:90-101

Price AH, Cairns JE, Horton P, Jones HG, Griffiths H (2002a) Linking drought-resistant mechanisms to drought avoidance in upland rice using a QTL approach: progress and new opportunities to integrate stomatal and mesophyll responses. J Exp Bot 53:989-1004

Price AH, Townend J, Jones MP, Audebert A, Courtois B (2002b) Mapping QTLs associated with drought avoidance in upland rice grown in the Philippines and West Africa. Plant Mol Biol 48:683-695

Rafalski JA (2010) Association genetics in crop improvement. Curr Opin Plant Biol 13:174-180

Raju NL, Gnanesh BN, Lekha P, Jayashree B, Pande S, Hiremath PJ, Byregowda M, Singh NK, Varshney RK (2010) The first set of EST resource for gene discovery and marker development in pigeonpea (Cajanus cajan L.). BMC Plant Biol 10:45

Ravi K, Vadez V, Isobe S, Mir RR, Guo Y, Nigam SN, Gowda MVC, Radhakrishnan T, Bertioli DJ, Knapp SJ, Varshney RK (2011) Identification of several small main-effect QTLs and a large number of epistatic QTLs for drought tolerance in groundnut (Arachis hypogaea L.). Theor Appl Genet 122:1119-1132

Rebetzke GJ, Chapman SC, Mcintyre L, Richards RA, Condon AG, Watt M, Van Herwaarden A (2009) Grain yield improvement in water-limited environments. In: Carve BF (ed) Wheat: science and trade. Wiley-Blackwell, Ames, IA, pp 215-249

Reddy AR, Ramakrishna W, Sekhar AC, Ithal N, Babu PR, Bonaldo MF, Soares MB, Bennetzen JL (2002) Novel genes are enriched in normalized cDNA libraries from drought stressed seedlings of rice (Oryza sativa L. subsp. indica cv. Nagina 22). Genome 45:204-211

Reynolds MP (2002) Physiological approaches to wheat breeding. In: Curtis BC, Rajaram S, Macpherson HG (eds) Bread wheat. FAO Plant production and protection series-30. http://www.fao.org/ docrep/006/y4011e/y4011e0a.htm\#bm10

Reynolds MP, Ortiz R (2010) Adapting crops to climate change: a summary. In: Reynolds MP (eds) Climate change and crop production, $\mathrm{CAB}$ international, pp 1-8

Reynolds MP, Trethowan RM (2007) Physiological interventions in breeding for adaptation to abiotic stress. In: Spiertz JHJ, Struik PC, van Laar HH (eds) Scale and complexity in plant systems research, gene-plant-crop relations. Wageningen UR frontis series, vol 21, pp 129-146

Reynolds MP, Tuberosa R (2008) Translational research impacting on crop productivity in drought-prone environments. Curr Opin Plant Biol 11:171-179 
Reynolds MP, Skovmand B, Trethowan R, Pfeiffer W (2000) Evaluating a conceptual model for drought tolerance. In: Ribaut J-M, Poland D (eds) Molecular approaches for the genetic improvement of cereals for stable production in water-limited environments: a strategic planning workshop held at CIMMYT, El Batan, Mexico, 21-25 June 1999. CIMMYT, Mexico, pp 49-53

Reynolds MP, Mujeeb-Kazi A, Sawkins M (2005) Prospects for utilising plant-adaptive mechanisms to improve wheat and other crops in drought- and salinity-prone environments. Ann Appl Biol 146:239-259

Reynolds MP, Dreccer F, Trethowan R (2007a) Drought-adaptive traits derived from wheat wild relatives and landraces. J Exp Bot 58:177-186

Reynolds MP, Saint Pierre C, Saad Abu SI, Vargas M, Condon AG (2007b) Evaluating potential genetic gains in wheat associated with stress-adaptive trait expression in elite genetic resources under drought and heat stress. Crop Sci 47:S-172-S-189

Reynolds MP, Manes Y, Izanloo A, Langridge P (2009a) Phenotyping approaches for physiological breeding and gene discovery in wheat. Ann Appl Biol 155:309-320

Reynolds MP, Foulkes JM, Slafer GA, Berry P, Parry MAJ, Snape J, Angus WJ (2009b) Raising yield potential in wheat. J Exp Bot 60:1899-1918

Reynolds MP, Bonnett D, Chapman SC, Furbank RT, Mane's Y, Mather DE, Parry MAJ (2011) Raising yield potential of wheat. I. Overview of a consortium approach and breeding strategies. J Exp Bot 62: 439-452

Ribaut JM, Ragot M (2007) Marker-assisted selection to improve drought adaptation in maize: the backcross approach, perspectives, limitations, and alternatives. J Exp Bot 58:351-360

Ribaut JM, Hoisington DA, Deutsch JA (1996) Identification of quantitative trait loci under drought conditions in tropical maize. 1. Flowering parameters and the anthesis-silking interval. Theor Appl Genet 92:905-914

Ribaut JM, Jiang C, Gonzalez-de-Leon D, Edmeades GO, Hoisington DA (1997) Identification of quantitative trait loci under drought conditions in tropical maize. 2. Yield components and markerassisted selection strategies. Theor Appl Genet 94:887-896

Ribaut JM, de Vicente MC, Delannay X (2010) Molecular breeding in developing countries: challenges and perspectives. Curr Opin Plant Biol 13:213-218

Richards RA (1991) Crop improvement for temperate Australia: Future opportunities. Field Crops Res 26:141-169

Rutkoski JE, Heffner EL, Sorrells ME (2010) Genomic selection for durable stem rust resistance in wheat. Euphytica 179:161-173

Salekdeh GH, Reynolds MP, Bennett J, Boyer J (2009) Conceptual framework for drought phenotyping during molecular breeding. Trends Plant Sci 14:488-496

Salem KFM, Roder MS, Borner A (2007) Identification and mapping quantitative trait loci for stem reserve mobilisation in wheat (Triticum aestivum L.). Cereal Res Commun 35:1367-1374

Salvi S, Tuberosa R (2005) To clone or not to clone plant QTLs: present and future challenges. Trends Plant Sci 10:297-304

Salvi S, Tuberosa R (2007) Cloning QTLs in plants. In: Varshney RK, Tuberosa R (eds) Genomics-assisted crop improvement, vol 1. Springer, New York, pp 207-226

Salvi S, Tuberosa R, Chiapparino E, Maccarerri M, Veillert S, Van Beuningen L, Isaac P, Edwards K, Phillips RL (2002) Toward positional cloning of $V g t 1$, a QTL controlling the transition from the vegetative to the reproductive phase in maize. Plant Mol Biol 48:601-613

Salvi S, Sponza G, Morgante M, Tomes D, Niu X, Fengler KA, Meeley R, Ananeiv EV, Svitashev S, Bruggemann E, Li B, Hainey CF, Radovic S, Zaina G, Rafalski JA, Tingey SV, Miao GH, Phillips RL, Tuberosa R (2007) Conserved noncoding genomic sequences associated with a flowering-time quantitative trait locus in maize. Proc Natl Acad Sci USA 104:11376-11381

Sanchez AC, Subudhi PK, Rosenow DT, Nguyen HT (2002) Mapping QTLs associated with drought resistance in sorghum (Sorghum bicolor L. Moench). Plant Mol Biol 48:713-726

Sanguineti MC, Tuberosa R, Landi P (1999) QTL analysis of drought related traits and grain yield in relation to genetic variation for leaf abscisic acid concentration in field-grown maize. J Exp Bot 50:1289-1297

Sanguineti MC, Li S, Maccaferri M, Corneti S, Rotondo F, Chiari T, Tuberosa R (2007) Genetic dissection of seminal root architecture in elite durum wheat germplasm. Ann Appl Biol 151:291-305

Saranga Y, Menz M, Jiang CX, Wright RJ, Yakir D, Paterson AH (2001) Genomic dissection of genotype $\times$ environment interactions conferring adaptation of cotton to arid conditions. Genome Res 12:1988-1995

Saranga Y, Jiang C, Wright R, Yakir D, Paterson AH (2004) Genetic dissection of cotton physiological responses to arid conditions and their inter-relationships with productivity. Plant Cell Environ 27:263-277

Sardans J, Peñuelas J, Lope-Piedrafita S (2010) Changes in water content and distribution in Quercus ilex leaves during progressive drought assessed by in vivo $1 \mathrm{H}$ magnetic resonance imaging. BMC Plant Biol 10:188

Schneider KA, Rosales-Serna R, Ibarra-Perez F, Cazares-Enriquez B, Acosta-Gallego JA, Ramirez-Vallejo P, Wassimi N, Kelly JD (1997a) Improving common bean performance under drought stress. Crop Sci 37:43-50

Schneider KA, Brothers ME, Kelly JD (1997b) Marker-assisted selection to improve drought resistance in common bean. Crop Sci 37:51-60

Sehgal D, Yadav R (2010) Molecular markers based approaches for drought tolerance. In: Jain SM, Brar DS (eds) Molecular techniques in crop improvement. Springer, New York, pp 207-230

Seiler C, Harshavardhan VT, Rajesh K, Reddy PS, Strickert M, Rolletschek H, Scholz U, Wobus U, Sreenivasulu N (2011) ABA biosynthesis and degradation contributing to $\mathrm{ABA}$ homeostasis during barley seed development under control and terminal drought-stress conditions. J Exp Bot 62:2615-2632

Serraj R, Hash CT, Rivzi SMH (2005) Recent advances in markerassisted selection for drought tolerance in pearl millet. Plant Prod Sci 8:334-337

Shen L, Courtois B, McNally KL, Robin S, Li Z (2001) Evaluation of near-isogenic lines of rice introgressed with QTLs for root depth through marker-aided selection. Theor Appl Genet 103:427-437

Shendure J (2008) The beginning of the end for microarrays? Nat Methods 5:585-587

Shinozaki K, Yamaguchi-Shinozaki K, Seki M (2003) Regulatory network of gene expression in the drought and cold stress responses. Curr Opin Plant Biol 6:410-417

Silim SN, Saxena MC (1993) Adaptation of spring-sown chickpea to the Mediterranean basin: I. Response to moisture supply. Field Crops Res 34:121-136

Sinclair TR (2011) Challenges in breeding for yield increase for drought. Trends Plant Sci 16:289-293

Sinclair TR, Ludlow MM (1986) Influence of soil water supply on the plant water balance of four tropical grain legumes. Aust J Plant Physiol 13:329-341

Sinclair TR, Purcell LC, Vadez V, Serraj R, King CA, Nelson R (2000) Identification of soybean genotypes with $\mathrm{N}_{2}$ fixation tolerance to water deficits. Crop Sci 40:1803-1809

Song-ping H, Hua Y, Gui-hua Z, Hong-yan L, Guo-lan L, Han-wei M, Run C, Ming-shou L, Li-jun L (2007) Relationship between coleoptile length and drought resistance and their QTL mapping in rice. Rice Sci 14:13-20 
Specht JE, Chase K, Macrander M, Graef GL, Chung J, Markwell JP (2001) Soybean response to water: a QTL analysis of drought tolerance. Crop Sci 41:493-509

Sreenivasulu N, Varshney RK, Kavi Kishor PB, Weschke W (2004) Functional genomics for tolerance to abiotic stress in cereals. In: Gupta PK, Varshney RK (eds) Cereal genomics, Kluwer Academic Publishers, New York, pp 483-514

Sreenivasulu N, Sopory SK, Kishor PBK (2007) Deciphering the regulatory mechanisms of abiotic stress tolerance in plants by genomic approaches. Gene 388:1-13

Sreenivasulu N, Sunkar R, Wobus U, Strickert M (2010) Array platforms and bioinformatics tools for the analysis of plant transcriptome in response to abiotic stress. Methods Mol Biol 639:71-93

Steele KA, Price AH, Shashidhar HE, Witcombe JR (2006) Markerassisted selection to introgress rice QTLs controlling root traits into an Indian upland rice variety. Theor Appl Genet 112:208-221

Steele KA, Virk DS, Kumar R, Prasad SC, Witcombe JR (2007) Field evaluation of upland rice lines selected for QTLs controlling root traits. Field Crops Res 101:180-186

Subudhi PK, Rosenow DT, Nguyen HT (2000) Quantitative trait loci for the stay-green trait in sorghum (Sorghum bicolor L. Moench): consistency across genetic backgrounds and environments. Theor Appl Genet 101:733-741

Talamè V, Ozturk NZ, Bohnert HJ, Tuberosa R (2007) Barley transcript profiles under dehydration shock and drought stress treatments: a comparative analysis. J Exp Bot 58:229-240

Tao YZ, Henzell RG, Jordan DR, Butler DG, Kelly AM, McIntyre CL (2000) Identification of genomic regions associated with staygreen in sorghum by testing RILs in multiple environments. Theor Appl Genet 100:1225-1232

Tardieu F, Tuberosa R (2010) Dissection and modelling of abiotic stress tolerance in plants. Curr Opin Plant Biol 13:206-212

Teulat B, This D, Khairallah M, Borries C, Ragot C, Sourdille P, Leroy P, Monneveux P, Charrier A (1998) Several QTLs involved in osmotic-adjustment trait variation in barley (Hordeum vulgare L.). Theor Appl Genet 96:688-698

Teulat B, Borries C, This D (2001a) New QTLs identified for plant water-status, water soluble carbohydrate and osmotic adjustment in a barley population grown in a growth-chamber under two water regimes. Theor Appl Genet 103:161-170

Teulat B, Merah O, Souyris I, This D (2001b) QTLs for agronomic traits from a Mediterranean barley progeny grown in several environments. Theor Appl Genet 103:774-787

Teulat B, Merah O, Sirault X, Borries C, Waugh R, This D (2002) QTLs for grain carbon-isotope discrimination in field-grown barley. Theor Appl Genet 106:118-126

Teulat B, Zoumarou-Wallis N, Rotter B, Salem MB, Bahri H, This D (2003) QTL for relative water content in field-grown barley and their stability across Mediterranean environments. Theor Appl Genet 108:181-188

Toker C, Canci H, Yildirim T (2007) Evaluation of perennial wild Cicer species for drought resistance. Genet Resour Crop Evol 54:1781-1786

Tsonev S, Todorovska E, Avramova V, Kolev S, Abu-Mhadi N, Christov NK (2009) Genomics assisted improvement of drought tolerance in maize: QTL approaches. Biotechnol Biotechnol Equip 23:1410-1413

Tuberosa R (2010) Phenotyping drought-stressed crops: key concepts, issues and approaches. In: Monneveaux P, Ribaut JM (eds) Drought phenotyping in crops: from theory to practice. Generation Challenge Programme, c/o CIMMYT, Mexico, pp 3-35

Tuberosa R, Salvi S (2006) Genomics approaches to improve drought tolerance in crops. Trends Plant Sci 11:405-412

Tuberosa R, Sanguineti MC, Landi P (1998) RFLP mapping of quantitative trait loci controlling abscisic acid concentration in leaves of drought-stressed maize (Zea mays L.). Theor Appl Genet 97:744-755

Tuberosa R, Sanguineti MC, Landi P (2002) Identification of QTLs for root characteristics in maize grown in hydroponics and analysis of their overlap with QTLs for grain yield in the field at two water regimes. Plant Mol Biol 48:697-712

UNEP (2009) Water: in the transition to a green economy: a UNEP brief available online at www.unep.ch/etb/ebulletin/pdf/ GE\%20and\%20Water\%20Brief.pdf

Varshney RK, Dubey A (2009) Novel genomic tools and modern genetic and breeding approaches for crop improvement. J Plant Biochem Biotechnol 18:127-138

Varshney RK, Graner A, Sorrells ME (2005) Genomics-assisted breeding for crop improvement. Trends Plant Sci 10:621-630

Varshney RK, Hiremath PJ, Lekha P, Kashiwagi J, Balaji J, Deokar AA, Vadez V, Xiao Y, Srinivasan R, Gaur PM, Siddique KHM, Town CD, Hoisington DA (2009a) A comprehensive resource of drought- and salinity responsive ESTs for gene discovery and marker development in chickpea (Cicer arietinum L.). BMC Genomics 10:523

Varshney RK, Nayak SN, May GD, Jackson SA (2009b) Nextgeneration sequencing technologies and their implications for crop genetics and breeding. Trends Biotechnol 27:522-530

Varshney RK, Bansal KC, Aggarwal PK, Datta SK, Craufurd PQ (2011) Agricultural biotechnology for crop improvement in a variable climate: hope or hype? Trends Plant Sci 16:363-371

Varshney RK, Paulo MJ, Grando S, van Eeuwijk FA, Keizer LCP, Guo P, Ceccarelli S, Kilian A, Baum M, Graner A (2012) Genome wide association analyses for drought tolerance related traits in barley (Hordeum vulgare L.). Field Crops Res 126:171-180

Venuprasad R, Dalid CO, Del Valle M, Zhao D, Espiritu M, Sta Cruz MT, Amante M, Kumar A, Atlin GN (2009) Identification and characterization of large-effect quantitative trait loci for grain yield under lowland drought stress in rice using bulk-segregant analysis. Theor Appl Genet 120:177-190

Vogel B (2009) Marker-assisted selection: a non-invasive biotechnology alternative to genetic engineering of plant varieties. In: Erwood S, Truchi N (eds) Smart breeding. Greenpeace International, The Netherlands, pp 4-25

von Korff M, Grando S, Del Greco A, This D, Baum M, Ceccarelli S (2008) Quantitative trait loci associated with adaptation to Mediterranean dry land conditions in barley. Theor Appl Genet 117:653-669

Wan J, Griffiths R, Ying J, McCourt P, Huang Y (2009) Development of drought-tolerant canola (Brassica napus L.) through genetic modulation of ABA-mediated stomatal responses. Crop Sci 49:1539-1554

Wang Xu-S, Zhu J, Mansueto L (2005) Identification of candidate genes for drought stress tolerance in rice by the integration of a genetic (QTL) map with the rice genome physical map. J Zhejiang Univ Sci-B 6:382-388

Welle R, Greten W, Rietmann B, Alley S, Sinnaeve G, Dardenne P (2003) Near-infrared spectroscopy on chopper to measure maize forage quality parameters online. Crop Sci 43:1407-1413

Wiley PR, Tanner GJ, Chandler PM, Anderssen RS (2009) Molecular classification of barley (Hordeum vulgare L.) mutants using derivative NIR spectroscopy. J Agr Food Chem 57:4042-4050

Worch S, Rajesh K, Harshavardhan VT, Pietsch C, Korzun V, Kuntze L, Börner A, Wobus U, Röder MS, Sreenivasulu N (2011) Haplotyping, linkage mapping and expression analysis of barley genes regulated by terminal drought stress influencing seed quality. BMC Plant Biol 11:1

Xiao YN, Li XH, George ML, Li MS, Zhang SH, Zheng YL (2005) Quantitative trait locus analysis of drought tolerance and yield in maize in China. Plant Mol Biol Repor 23:155-165 
Xu W, Subudhi PK, Crasta OR, Rosenow DT, Mullet J, Nguyen HT (2000) Molecular mapping of QTLs conferring stay-green in grain sorghum (Sorghum bicolor L. Moench). Genome 43:461-469

Xu Y, Skinner DJ, Wu H, Palacios-Rojas N, Araus JL, Yan J, Gao S, Warburton ML, Crouch JH (2009) Advances in maize genomics and their value for enhancing genetic gains from breeding. Int $\mathrm{J}$ Plant Genomics. doi:10.1155/2009/957602

Yadav R, Courtois B, Huang N, McLaren G (1997) Mapping genes controlling root morphology and root distribution in a doubledhaploid population of rice. Theor Appl Genet 94:619-632

Yadav RS, Hash CT, Bidinger FR (2002) Quantitative trait loci associated with traits determining grain and stover yield in pearl millet under terminal drought stress conditions. Theor Appl Genet 104:67-83

Yadav RS, Sehgal D, Vadez V (2011) Using genetic mapping and genomics approaches in understanding and improving drought tolerance in pearl millet. J Exp Bot 62:397-408

Yang J, Zhang J (2006) Grain filling of cereals under soil drying. New Phytol 169:223-236

Yang DL, Jing RL, Chang XP, Li W (2007) Identification of quantitative trait loci and environmental interactions for accumulation and remobilization of water-soluble carbohydrates in wheat (Triticum aestivum L.) stems. Genetics 176:571-584
Yang S, Vanderbeld B, Wan J, Huang Y (2010) Narrowing down the targets: towards successful genetic engineering of droughttolerant crops. Mol Plant 3:469-490

Yin X, Struik PC, Kropff MJ (2004) Role of crop physiology in predicting gene-to-phenotype relationships. Trends Plant Sci 9:426-432

Zaman-Allah M, Jenkinson DM, Vadez V (2011a) A conservative pattern of water use, rather than deep or profuse rooting, is critical for the terminal drought tolerance of chickpea. J Exp Bot 62:4239-4252

Zaman-Allah M, Jenkinson DM, Vadez V (2011b) Chickpea genotypes contrasting for seed yield under terminal drought stress in the field differ for traits related to the control of water use. Func Plant Biol 38:270-281

Zhang J, Dell B, Conocono E, Waters I, Setter T, Appels R (2009) Water deficits in wheat: fructan exohydrolase (1-FEH) mRNA expression and relationship to soluble carbohydrate concentrations in two varieties. New Phytol 181:843-850

Zheng BS, Yang L, Zhang WP (2003) Mapping QTLs and candidate genes for rice root traits under different water-supply conditions and comparative analysis across three populations. Theor Appl Genet 107:1505-1515

Zhou L, Liu Y, Liu Z, Kong D, Duan M, Luo L (2010) Genome-wide identification and analysis of drought-responsive microRNAs in Oryza sativa. J Exp Bot 61:4157-4168 